\title{
Getting the specialization right. Industrialization in Southern China in a sustainable development perspective.
}

\author{
Authors: \\ Elisa BARBIERI ${ }^{A}$, Marco R. DI TOMMASO ${ }^{B}$, Chiara POLLIO $^{\mathrm{CB} *}$, Lauretta RUBINI ${ }^{\mathrm{B}}$ \\ A University of Venice Ca' Foscari (Italy)-Department of Economics \\ ${ }^{\mathrm{B}}$ University of Ferrara (Italy) - Department of Economics and Management \\ ${ }^{\mathrm{C}}$ Emilia $^{\text {Lab }}$, Network of the Departments of Economics of Emilia-Romagna Region \\ ${ }^{*}$ Corresponding author: \\ University of Ferrara - Via Voltapaletto, 11 - 44121 Ferrara (ITALY) \\ chiara.pollio@unife.it \\ Phone: +390532455085 \\ Fax: +390532205349
}

\section{Declarations of interest: none}

Acknowledgements: We would like to thank the editor and the two anonymous reviewers for the throughout comments. This research did not receive any specific grant from funding agencies in the public, commercial, or not-for-profit sectors.

Abstract: Information and communication technologies (ICT) are acknowledged as a powerful tool used to foster development and to broaden people's agency. This being so, ICT are also the results of specific production processes. And, little attention has been given to the degree of sustainability that the places that are currently in charge of producing ICT attain. In this framework, we investigate under what conditions specializing in ICT products rewards a territory in terms of technological innovation and socially sustainable development. Our analysis focuses on the case of Dongguan city, China, which is a core area in the global production of ICT. Industrialization in this area has been mainly FDI-led and framed within a Province-level industrial specialization policy - the Specialized Towns program. We perform an empirical analysis based upon a unique township-level dataset covering several years (2000-2016). We then integrate the quantitative data with qualitative fieldwork information on Dongguan ICT-specialized townships. Our findings suggest that (1) specializing in ICT can pay in terms of innovative performances, provided it is supported by an institutional setting aimed at collectively promoting innovation, a sufficient degree of extra-cluster relations and a 
sufficiently high level of education of the population. (2) Social sustainability can be improved in ICT clusters by long experience in public involvement towards building collective action. Since many of these areas do not currently show to have reached such social and economic conditions, they risk being captured in a middle income-low development trap. Governments targeting ICT specialization should then focus also on devoting specific policy initiatives towards social inclusion.

\section{Highlights:}

- We focus on ICT clusters performance in technological innovation and especially in terms of socially sustainable development

- We analyze ICT clusters within the specialized town program in Dongguan city, Southern China

- Educated local population and foreign linkages improve ICT clusters' innovation

- Social sustainability can be improved in ICT clusters by long experience in public involvement towards building collective action

Keywords: Innovation, Social Sustainability, ISID, China, Specialized Towns, ICT

JEL: O3; O35; O38; O25; L63 
Both traditionally and in recent times, industrial development has been identified as one of the drivers of economic growth and poverty alleviation (Haraguchi, 2017). Industrialization processes have also entered the international debate about sustainability given their potential to promote innovation and provide decent jobs (European Commission, 2010). Inclusive and Sustainable Development (ISID), intended as an industrialization process providing fair involvement and rewards to large strata of global population (UNIDO, 2015a), has indeed been promoted as a leading strategy within the UN agencies, connecting social, environmental and economic aspects of development to achieve the Sustainable Development Goals (SDGs). Goals 8 (Promote inclusive and sustainable economic growth, employment and decent work for all), 9 (Build resilient infrastructure, promote sustainable industrialization and foster innovation) and 12 (Ensure sustainable consumption and production patterns) highlight the role of good industrial practices in contrasting the multidimensional features of unsustainable growth. Increasingly, ISID points out that the discussion is no longer about whether governments should promote industrialization, but what kind of industrialization they should promote (UNIDO, 2015a). In particular, Agenda 2030 for Sustainable Development stresses that this should entail new models of responsible consumption and production, decent jobs, environmental sustainability and no one being left behind by unbalanced processes of growth (United Nations, 2015).

One of the most important mechanisms triggered by industrialization to achieve inclusive development rests in technology and innovation (SDG 9). Even the economic success of a country relates to the extent to which structural changes of the economy are coupled with technological catchup and the country's ability to produce innovation (Lavopa \& Szirmai, 2018). In this framework, new technologies and ICT are key tools in connecting people and territories and empowering large strata of the population (United Nations, 2018). This is in line with a long-lasting debate about the possible benefits of ICT diffusion (Niebel, 2018): such benefits are mainly studied from the end-users 
perspective $^{1}$, be they either people, companies or governments (Asongu \& Le Roux, 2017) and are recognized as essential tools for Agenda 2030 for sustainable development (Sachs, 2012; United Nations, 2018).

However, while the risks and benefits associated with ICT on the consumption side are acknowledged, ICT has to be considered also as the output of specific manufacturing processes; it represents a distinct manufacturing sector, located in specific places around the world. This being so,such places do not necessarily correspond to the final markets for ICT products and, particularly when they are in developing countries, they are more likely to become export hubs (Steinmueller, 2001; Xing, Ye \& Kui, 2011). The impact of this specific production on the hosting communities has been rather neglected (Hughes, Bohl, Irfan, Margolese-Malin \& Solórzano, 2017; NLC, 2009). In other words, special attention should also be given to the social sustainability - broadly defined as a set of conditions that allow improving living conditions of current and future generations (Boström, 2012) - of the territories engaged in ICT production. From this perspective the issue of what is happening to the places that produce ICT to the benefit of the rest of the world arises. Are they experiencing innovation and socially sustainable development thanks to their specialization in this particular sector? Again, what are the conditions that make ICT specialization a "good choice" in terms of innovation and development? These are the driving questions of this paper.

Recent contributions have suggested that regions, and even more so cities and clusters, are the most appropriate units of analysis to understand economic and social change dynamics in contemporary economies (Barca, McCann \& Rodríguez-Pose, 2012; Garretsen, McCann, Martin \&

\footnotetext{
${ }^{1}$ Increased connectivity among people and among economic agents is proved to be correlated with gains in productivity and efficiency for economic and social systems (Disney, Naim \& Potter, 2004; Ollo-López \& Aramendía-Muneta, 2012, only to cite some). It is also positively associated with social inclusion, by improving people's access to goods and - both private and public - services, giving new answers to old needs and potentially enhancing human capabilities (Balauskat, Blamire \& Kefala, 2012; Capriati, 2017; Lyons, 2009). New communication technologies have become one of the most powerful tools for social change, allowing for new forms of social, political and economic organization (Lechman \& Marszk, 2015; Linders, 2012). They even show to be positively correlated with environmental sustainability in relation to various fields such as transportation, land use, manufacturing, energy (see Gouvea, Kapelianis \& Kassicieh, 2017 for a deeper dissertation on this).
} 
Tyler, 2013; Giuliani, Pietrobelli \& Rabellotti, 2005; Iammarino, 2018). This immediately indicates that attention needs to be placed on the clustered dimension of industrialization.

Within the extremely vast literature on clusters, some recent contributions have suggested a renewed theoretical framework, accounting for multiple possible paths of development for any cluster including the post-maturity stage (Martin, 2010). In other words, whether a cluster is deemed to reach stasis and lock-in or rather renew itself is inherently an empirical question (Martin, 2010). There is therefore still room for further investigation on clusters experiences, particularly in emerging economies (Morrison, Pietrobelli \& Rabellotti, 2008; Yang, Matohashi \& Chen, 2009).

Furthermore, while clusters' growth, competitiveness and innovation have been largely studied (Baptista, 2000; Bell \& Albu, 1999; Breschi \& Malerba, 2005; Thompson, 2002, only to cite some), social and human development has remained much more marginal. It has been explored by the literature on Italian industrial districts (Becattini, 1990; Becattini, Bellandi \& De Propris, 2009; Bellandi, 2002; Piore \& Sabel, 1986), which even so, mainly dealt with light industries, given the specialization of these localities. In the specific context of high-tech clusters, there is a lack of evidence on the conditions allowing social sustainability (de Oliveira, 2008; Etzkowitz, 2013), particularly in relation to clusters in developing world, for which the main focus has been on innovation and economic performances (Giuliani et al., 2005; Manning, Ricart, Rosatti Rique \& Lewin, 2010; Wang, Lin \& Li, 2010; Zhou, 2013). In mature economies, even those ICT clusters generally acknowledged as success cases, such as Silicon Valley, are recently showing weaknesses in terms of social sustainability (Etzkowitz, 2013; Pellow \& Park, 2002; Pique, Berbegal-Mirabent \& Etkowitz, 2018).

With these premises, we analyze the experience of Dongguan city, in the Guangdong Province of Southern China. This relatively small city - with a permanent population similar to that of Switzerland on an area no larger than Luxembourg ${ }^{2}$ - has witnessed an impressive growth in ICT

\footnotetext{
${ }^{2}$ In 2015 (last available data) Dongguan's permanent population summed up to 8,254 million, while its land covers 2.460 square kilometres. Source: Guangdong Statistical Office (2016).
} 
production, becoming a world hub in this field in a matter of years (Wang \& Lin, 2008; Zhou, 2013; Zhou, Sun, Wei \& Lin et al., 2011). In 2016, one sixth of all the smartphones sold worldwide was manufactured in this city $^{3}$. The organization of ICT production and, in general, of the whole manufacturing in Dongguan, is structured around industrial clusters. Such social organizations of production have been officially recognized since the early 2000 s within the framework of the Guangdong Province "Specialized Towns Program" (Barbieri, Di Tommaso, Pollio and Rubini, 2019; Bellandi \& Di Tommaso, 2005; Di Tommaso, Rubini \& Barbieri, 2013; Lu, 2006), which is a specific example of how regional governments in China deeply affect local industrial dynamics (Cai \& Sun, 2018; Ratigan, 2017; Zhang \& Hu, 2014). Additionally, Dongguan's industrial clusters have initially developed under the influence of exogenous forces. Since the beginning, the main source of capital has been FDI coming from neighboring areas that had an interest in this particular city as an export hub, given its locational advantages. Subsequent industrial growth has attracted abundant inflows of migrant populations from rural areas (Shen \& Tsai, 2016; Yang, 2007; Yang \& Liao, 2010).

All these aspects, namely Dongguan FDI-led growth, its policy-induced specialization and its productive focus on ICT, make this city a special case study to analyze the linkage between policies, high-tech specialization and sustainable development.

Some papers have analyzed Dongguan ICT through case studies or macroeconomic analyses (Lin, Wang, Zhou, Sun \& Wei, 2011; Sun \& Zhou, 2011; Zhou, 2013; Zhou et al., 2011, only to cite some), whereas others have stressed social change dynamics occurring as a consequence of rapid industrialization in the area (see for example Ip, 2014; Lin, 2006; and Liu \& Ye, 2015). However, as far as we know there is no comprehensive evaluation of the degree of innovation and social development that ICT clusters have achieved in Dongguan, promoted by the Specialized Towns (STs) program. With this paper, we test which distinctive social, economic and institutional features can enable ICT specialized clusters to promote innovation and social sustainability. To do this we have

\footnotetext{
${ }^{3}$ https://news.cgtn.com/news/3d557a4d32454464776c6d636a4e6e62684a4856/share_p.html
} 
adopted a mixed-method approach, building on both qualitative information gathered through fieldworks and interviews, and quantitative data collected from an original township-level dataset (2001-2015). We empirically test the existence of two types of relations: between ICT specialization and innovative outputs of specialized townships and, subsequently, between ICT specialization and a number of tailored social development measures, including measurements of human development.

The paper is organized as follows: section 2 reviews the mechanisms acknowledged by the literature that link ICT clustering and innovation, on the one hand, and ICT clustering and development, on the other, and includes the hypotheses; section 3 describes the methodology; section 4 provides a description of the institutional STs Program setting and frames the experience of Dongguan within it. Section 5 presents the empirical analysis and discusses the results. Section 6 concludes.

\section{Literature Review}

\subsection{Clusters, ICT and innovation}

Since Marshall's seminal work of (1890), further contributions have suggested that territorial specialization and spatial proximity among firms increase innovative capability (Bell \& Albu, 1999; Porter, 1999). This is mainly due to localized learning processes and inter-firm networking that facilitate the diffusion of knowledge (Baptista, 2000; Bell, 2005; Breschi \& Malerba, 2005); knowledge externalities among firms (Baptista \& Swann, 1998; Cappellin, 2009); and, co-location within the cluster of valuable customers that allow an improved knowledge of the market (Porter, 1999). Other papers, however, have highlighted that clustering is not innovative per se: although proximity creates a potential for interaction, the result in terms of networking and knowledge spillovers strongly depends on the willingness of firms to participate (Wang, 2009; Okamuro \& Nishimura, 2013). Furthermore, mere interaction may again be insufficient in increasing the innovative capacity of the cluster, because some sort of coordination in the competitive dynamics among firms is needed in order to transform the interaction into an innovative effort. In this sense, 
the presence of institutions such as technological innovation centers may facilitate the ignition of innovative networking processes.

Part of this literature has suggested that clusters specialized in some sectors, like the hightech, are inherently characterized by higher degrees of knowledge and innovativeness (Bresnahan \& Gambardella, 2004; Chesbrough, 2003; Coad \& Rao, 2008; He \& Fallah, 2011; Keeble \& Wilkinson, 1999). At the same time, other contributions such as the global value chain approach, point out that rather than the sector, what really matters is the specific phase of the production process that firms and clusters cover (Chen, 2004; Giuliani et al., 2005; Pietrobelli \& Rabellotti, 2011; Wang et al., 2010). Some scholars suggest, for instance, that upgrading clusters are more likely to experience higher degrees of technological innovation (Giuliani et al., 2005; Rocha, 2004). Among high-tech clusters, several authors have focused on ICT with the underlying idea that they are particularly effective in igniting innovation processes, hence favoring the economic enhancement of firms, regions and countries (see, among others, Lee, Lee \& Yoon, 2011; Rasiah, Shahrivar \& Yap, 2016; Wang et al., 2010). Also, in this case, and analogously to other high-tech sectors, the presence of linkages and knowledge spill-overs among co-located firms is important for strengthening their innovative potential (Keeble \& Wilkinson, 1999).

However, especially in developing countries, these mechanisms of efficiency diffusion among firms may encounter some friction (Wang et al., 2010). In many of these cases, in order to foster its innovative capacity, the cluster needs to rely on a network of extra-cluster linkages, such as FDI or trade flows, allowing firms to acquire the qualified knowledge they lack and are not able to produce internally (Chandrashekar \& Subrahmanya, 2019; Elliott \& Zhou, 2015; Eraydin \& Armatli-Köroğlu, 2005; Wang et al., 2010). Another important element boosting the innovative capacity of the cluster is the presence of high levels of education which facilitate the endogenous production of innovation. In fact, the lack of a sufficiently qualified workforce is among the obstacles hindering the upgrading of Chinese agglomerations (Wei, Li \& Wang, 2007), and it has induced several ICT clusters in China to "import" specialized talents from outside, when possible (Lai, Chiu, Leu, 2005). 
This evidence leads us to the hypotheses, which mainly aim, in this first step of the analysis, at verifying if the results highlighted in the literature also hold for the Dongguan case.

H1: Compared to clusters specialized in other sectors, ICT clusters perform better in terms of innovation if they display a sufficiently high level of extra-cluster linkages.

H2: Compared to clusters specialized in other sectors, ICT clusters perform better in terms of innovation if they display a sufficiently high level of educated population.

\subsection{Clusters, ICT and social development}

Within the broader literature on sustainable development (Anand \& Sen, 2000; Lele, 1991; Tisdell, 1988; WCED, 1987), social sustainability is considered as one of the three conceptual pillars, together with ecological and economic sustainability (Boström, 2012). Nonetheless, social sustainability concept has been integrated later than the others, it is the least developed of the three and lacks of a generally accepted definition (Eizenberg \& Jabareen, 2017; Magis \& Shinn, 2009; Shirazi \& Keivani, 2017). In general, social sustainability has been understood as a set of procedural and substantive aspects that improve people's living conditions, both in terms of current and future generations (Boström, 2012). On the one hand, this implies that to be sustainable societies should be able to maintain and reproduce their social conditions (Littig \& Grießler, 2005; Vallance, Perkins \& Dixon, 2011). On the other hand, the literature asserts that this concept emphasizes social justice and equity, alleviating poverty and offering equal opportunities. In other words, it is a reflection of the kind of communities and social values that are supported and reproduced (Boström, 2012; Cuthill, 2009; Eizenberg \& Jabareen, 2017). Additionally, various contributions have underlined that, next to fulfilling basic needs and expanding opportunities for a larger stratum of population, social sustainability should also include the society's ability to integrate people within social networks, build cohesive communities and reinforc a sense of place (Dempsey, Bramley, Power \& Brown, 2011; Eizenberg \& Jabareen, 2017; Littig \& Grießler, 2005). Indeed, many aspects of social sustainability, 
and explicitly those related to opportunities and needs, are not far from Sen's (1997) concept of development. From this point of view, social sustainability has been proxied in several cases by human development indicators (see for example Dhahri \& Omri, 2018; Strezov, Evans \& Evans, 2017). However, it has also been stated that the various and sometimes conflicting dimensions (Godschalk, 2004) of social sustainability need to be assessed with a set of indicators, related to human basic needs and quality of life, equal opportunities and inclusion (Littig \& Grießler, 2005).

Within this broad spectrum, the promotion of clustered industrialization has been identified as one of the key tools to promote ISID strategies in East Asia (UNIDO, 2015b). Nevertheless, when promoting clusters, it has to be underlined that the social dimension of economic development is not a characterizing feature of clusters studies (Porter \& Ketels, 2009). The literature on Italian industrial districts (Becattini, 1990; Becattini et al., 2009; Bellandi, 2002; Dei Ottati, 2002; Piore \& Sabel, 1986) is among the few exceptions. Such studies underscore that, to promote collective welfare in industrial districts, there must be a "community of people" sharing some fundamental values, collective participation in the social and economic life, frequent formal and informal exchanges across actors (Becattini \& Dei Ottati, 2006; Pyke \& Sengenberger, 1990).

Given that the historical and geographical embeddedness of production seems to be a precondition for social development of industrial districts, a debate has arisen on the role of exogenous actors and on the integration of such districts within global value chains. Exogenous economic forces are important to transfer knowledge and technologies and thus possibly favor district upgrading and long-term economic survival (Chiarvesio, Di Maria \& Micelli, 2010; Mariotti, Mutinelli \& Piscitello, 2008; Menghinello, De Propris \& Driffield, 2010). Yet, such forces might cause shocks on the balances of relations among actors and generate social exclusion (De Marchi \& Grandinetti, 2014).

However, authors investigating the nexus between clusters and development, especially in developing countries, have highlighted significant differences from industrial districts' model. 
First, while the interrelations among actors in industrial districts are mainly spontaneous and entrenched in the history of the locality, in clusters joint action among actors does not always arise spontaneously (Nadvi \& Barrientos, 2004). In these cases, hence, policies can play a role in building platforms to favor the relations among firms and with institutions, thereby facilitating the diffusion of knowledge and disseminating social benefits to the local community (Asadullah \& Savoia, 2018; Garretsen et al., 2013). This is in line with the emphasis placed on the contribution of effective policymaking by international organizations in fostering ISID processes, particularly at the local level (UNIDO, 2015a; 2015b). Still, one can expect that policies promoting social relations require time in order to have an impact on social sustainability. This is even more to the point in the case of ICT in developing countries, which has often been directed more by the international strategies of multinational actors than by local forces. Being ICT one of the most internationalized and fragmented sectors (Amighini, 2005; Gangnes \& Van Assche, 2012), it is reasonable to expect that in this case local industrial policies aimed at favouring social networking and joint actions would take time to produce measurable effects.

From the above discussed literature, the following hypothesis stems:

H3: ICT clusters perform better in terms of social sustainability if they display a longer experience of public involvement in promoting collective actions.

Finally, some contributions have highlighted the linkage between innovation and human development that, through learning processes and improvement in human capital, should widen individual and collective agency (Capriati, 2017; Lundvall, 2007; Lundvall, Joseph, Chaminade \& Vang, 2009; Sen, 1997). For clustered productions, and in particular in developing countries, these assumptions are complemented by studies suggesting that not all clusters impact equally on the social dimension of development, and that this might be related to their innovative activities and upgrading capabilities (Nadvi \& Barrientos, 2004; Rocha, 2004). As regards ICT, the sector is at the core of a new technological paradigm and strongly pulled by an increasing demand worldwide and across 
different industries (Castellacci, 2008; Min \& Lu, 2007). This makes it one of the most dynamic and innovative sectors of contemporary economy and one of the most powerful sources of technological upgrading. We therefore expect the chances of innovation to be higher in this sector.

This leads to the fourth hypothesis:

H4: Compared to clusters specialized in different sectors, ICT clusters perform better in terms of social sustainability if they display a significant level of technological upgrading.

\section{Methodology}

Given the plurality of actors involved and the complexity of the social and institutional framework that we wish to analyze, we have decided to adopt a mixed-method approach (Cairns, 2018; Goertz, 2017; Hesse-Biber \& Johnson, 2015), by complementing a quantitative empirical analysis, with qualitative information gathered during an on-site investigation in Guangdong Province (July-September 2017).

To perform the empirical analysis, we built an original panel dataset on Dongguan townships from various sources, with a specific focus on information related to industrial specialization. First, we collected information about the product and the year of specialization of each specialized tow, from the Association of Specialized Towns of Guangdong (Potic) and the Department of Science and Technology of Guangdong (hereafter DTSGG) as recognized by the STs Program (see section 4).. Subsequently, we classified the specialization product according to standard international classifications (ISIC Rev.4) to identify ICT clusters.

We matched this information with a rich set of data by towns collected from the Dongguan statistical yearbooks (2000-2017). The data was then set at in an original balanced panel dataset containing information on all Dongguan townships (32) for the period 2001-2016. Additional information about the data is presented in section 5 . 
In order to complement the quantitative analysis, we use qualitative information, as other disciplines do (Gill, Stewart, Treasure \& Chadwick, 2008; Pope \& Mays, 1995), to acquire a deeper understanding of the history and development of the STs phenomenon. We gathered such information through interviews to purposive samples and focus groups organized during the fieldwork. Based on our previous knowledge of STs and clustering programs in Guangdong (Barbieri, Di Tommaso \& Bonnini, 2012; Bellandi and Di Tommaso, 2005; Di Tommaso et al., 2013), we identified a group of institutional actors that are involved in economic and social planning, innovation and clustering in the province (Table 1). A full list of these can be found in the Appendix. We developed a questionnaire with open-ended questions to perform semi-structured interviews (approximately 2.5 hours each) that we administered in person to institutional qualified witnesses of the STs Program. We also interviewed Chinese academic experts directly involved in the STs initiative. Questions concerned the linkages between cluster planning and innovation activity, the relationship between ICT production and local social transformations and, the prospects and obstacles to further economic and social development of these areas. ${ }^{4}$

Table 1. Affiliation of respondents

\begin{tabular}{lc}
\hline Institutions & Number of interviews \\
\hline Policy-making institutions & 5 \\
Local (township level) governments' representatives & 5 \\
Academic experts (think-tanks included) & 11 \\
\hline
\end{tabular}

\section{Innovative institutional setting: the experience of specialized towns}

Building on the results of our fieldwork and on the existing literature, we introduce a first thorough picture of the recent experience of Guangdong clusters.

Clusters in Guangdong seem to display a number of distinctive features compared to the experience of other industrial agglomerations in China (Barbieri et al., 2012; Bellandi and Di Tommaso, 2005; Christenson \& Lever-Tracy, 1997; Di Tommaso et al., 2013; Lai et al., 2005; Wang and Yue, 2010 among the others).

\footnotetext{
${ }^{4}$ Interviews were conducted in English and Chinese with the support of a professional translator.
} 
The first important aspect is the peculiar institutional setting that the government of Guangdong, through the DSTGG, has developed to coordinate and promote innovation within these clusters. Many STs found their start in the Spark Plan launched by the Chinese government at the end of the ' 80 s, however, in the early 2000s the STs Program became a separate and unique policy program aimed at coordinating a fast industrialization process while promoting innovation (Barbieri, Di Tommaso \& Rubini, 2009a, 2009b; Bolognini, 2000; DSTGG, 2003; Di Tommaso and Rubini, 2006; Luo and Zhu, 2015).

The institutional setting envisaged by the program involves a system of certifications ${ }^{5}$ awarded to towns and includes specific policy actions implemented by different layers of government. Technological innovation is at the center of the STs Program, which basically finances investment in innovation platforms and services. Once the certification is obtained, certified STs are entitled to receive a subsidy from the DSTGG, provided that an additional part is financed by the local government where the ratio of province to city to town stands at 1, 10, 50, respectively (Wang, 2009; Wang \& Yue, 2010). The subsidy is given to finance the establishment of an innovation center or platform. In the view of Guangdong policymakers, innovation platforms have multiple functions to the benefit of all the firms in the cluster. Initially, they are designed to help firms with the development of new technologies and production upgrading. In addition, they aim at encouraging the cooperation among the different economic and institutional actors of the town, connecting private firms and public research institutions to foster innovative projects (Barbieri, Di Tommaso \& Huang, 2010; DSTGG, 2017; GDASS, 2017). In doing so, the activity of the innovation centers is expected to help improve the reputation of the whole productive system of the town and possibly support the development of common brands (Arvanitis \& Qiu, 2004; DSTGG, 2003, 2006; Wang, 2004). The interviewed policy

\footnotetext{
${ }^{5}$ In order to be certified as "specialized", towns must meet some specific criteria. First, from the administrative point of view the cluster must be identifiable with a township (even though occasionally there are cases of different administrative units, such as urban districts or counties, recognized as "specialized towns"). Second, at least $30 \%$ of its industrial production should come from the specialized industry (defined in specific sectoral terms, analogously to international three-digit classification systems). Finally, the township as a whole should generate an industrial output of at least 2 billion Yuan (Di Tommaso et al., 2013).
} 
actors asserted that in recent years the DTSGG has tried to create a competitive market for innovation centers, where several services centers are created and encouraged to compete for the supply of services to the companies in the town. Innovation centers mostly follow a market logic in their everyday activities and strategic choices, while maintaining associations with the political and funding actors. In fact, it is very common that the board of directors includes representatives from the political authorities that funded the innovation platform.

Notwithstanding this common institutional setting, the literature has distinguished between exogenous and endogenous clusters, according to whether they were mainly triggered by policies attracting foreign direct investment (FDI) or by local factors, respectively (Bellandi \& Di Tommaso, 2005; Wang, 2009; Wang \& Yue, 2010).

STs are not a marginal phenomenon in Guangdong. Since the launch of the program (2000), the number of STs has constantly grown and reaching a number of 416 in 2017 (Figure 1). In 2015, they accounted for $37 \%$ of the provincial industrial output and $32 \%$ of the total export of the province, but in some prefectures (e.g. Foshan, Dongguan) their contribution was close to $100 \%$ of the output: considered their sum output, they produce nearly 384Billion US\$ a year (GDASS, 2017). Also, these towns notably contribute to innovation in Guangdong. In fact, about $39 \%$ of total patent applications and $31 \%$ of applications for inventions in the province come from these clusters. Most remarkably, $65 \%$ of all large enterprises that have $R \& D$ internal institutions are based in these towns. In this setting, innovation centers play a leading part: in 2015, for instance, they completed 620 projects and produced more than a 3 million yuan output ${ }^{6}$ across the whole province ${ }^{7}$.

Figure 1. Specialised towns in Guangdong.

\footnotetext{
${ }^{6}$ One yuan corresponds to 0.15 US dollars.

${ }^{7}$ All data are elaborated by the authors based on information retrieved from the Guangdong Statistical Office (2016), the GDASS (2017) and from the DSTGG (2016).
} 


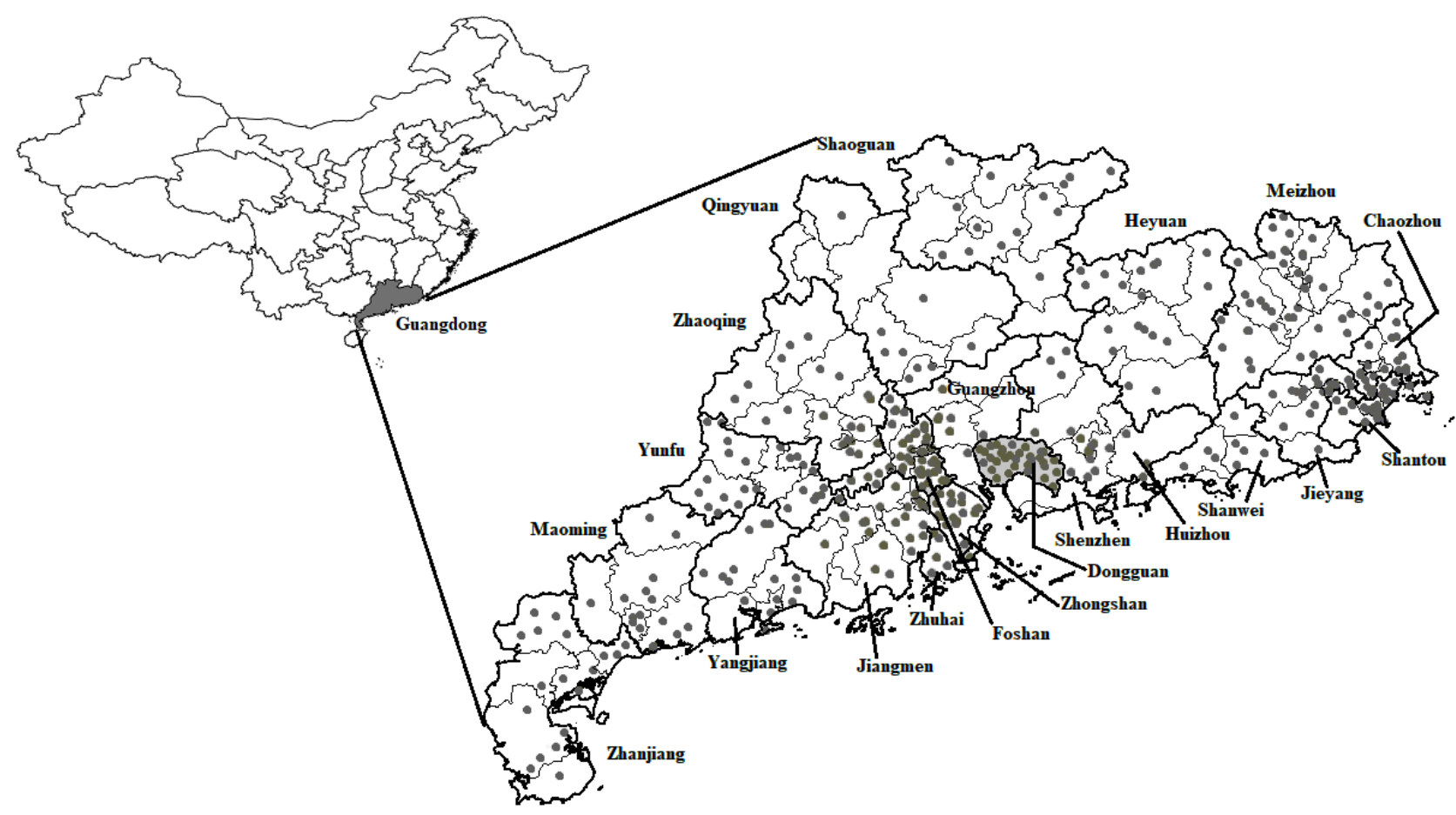

Source: Authors' elaborations on data from Guangdong Provincial ST Development Promotion Association.

Notes: Each dot identifies a ST. The dark grey area on China's map identifies Guangdong province, while the grey area on Guangdong's map identifies Dongguan city. The 17 new towns recognized from 2015 to 2017 are not reported as data is unavailable.

In this framework, the Dongguan experience is particularly important. This prefecture has been a pioneering force for the growth of industrial clusters. The first ST in Dongguan was recognized in 2000, just at the launch of the STs Program. Nowadays, all but two of the thirty-two Dongguan towns have been officially recognized as specialized clusters, meaning that the whole prefecture's production is basically organized around STs (Yang \& Liao, 2010).

Dongguan STs seem to show distinctive features compared to others. First, they are among the largest in terms of both total and specialized output (DSTGG, 2016). Additionally, STs in Dongguan seem to be particularly innovative with respect to towns in other areas of the Province. According to 2015 data, Dongguan STs show on average higher figures compared to other cities' towns in various indicators of innovation inputs and outputs (see Table 2).

\begin{tabular}{lccc}
\hline & Average per total STs & $\begin{array}{c}\text { Average per STs in } \\
\text { Dongguan }\end{array}$ & $\begin{array}{c}\text { Dongguan's STs } \\
\text { percent weight on total }\end{array}$ \\
\hline $\begin{array}{l}\text { Investment in Science and Technology (10,000 } \\
\text { yuan) }\end{array}$ & 991.24 & 3818.84 & 30.85 \\
Of which public investments (10,000 yuan) & 111.41 & 428.65 & 32.78 \\
\hline
\end{tabular}




\begin{tabular}{|c|c|c|c|}
\hline Patent applications & 351.26 & 1097.88 & 26.63 \\
\hline Of which inventions & 80.89 & 288.82 & 30.42 \\
\hline Patent licenses & 236.58 & 802.29 & 28.89 \\
\hline Of which inventions & 17.65 & 70.71 & 34.14 \\
\hline Number of enterprises with R\&D offices & 8.137 & 42.118 & 44.10 \\
\hline Number of innovation services providers & 7.27 & 15.32 & 17.96 \\
\hline $\begin{array}{l}\text { Number of scientific and technology institutes } \\
\text { established by public institutions }\end{array}$ & 1.93 & 4.94 & 21.84 \\
\hline
\end{tabular}

Table 2. Innovation in STs: comparing Dongguan with the remaining Guangdong province, year 2015

Source: authors' elaboration on DSTGG data.

Finally, 29 out of the 30 STs of Dongguan appear in the Top 100 ranking according to the 2016 Innovation Index, which was used by the DSTGG to evaluate STs innovation performances (GDASS, 2017).

Dongguan results as a core area in the development of the ICT industry in the whole Guangdong. Born as Shenzhen's back factory (Zhou, 2013), its ICT industrial production has grown under the influx of Taiwan and Hong Kong (Shen \& Tsai, 2016; Yang \& Liao, 2010) and in 2000s it became the world center for labor-intensive component manufacturing (Zhou et al., 2011), as well as the home of important companies such as Huawei.

Together with Shenzhen, it is the place where the majority of Chinese ICT production is realized and exported all over the world (Lai et al., 2005; Zhou, 2013). According to data provided by the Guangdong Statistical Office (2016), more than $88 \%$ of Dongguan high-tech value added is contributed by ICT production. By contrast, ICT in Dongguan is still characterized by assembly functions or low value added activities (Sun \& Grimes, 2016): in fact, the ratio of ICT value added on total output in the city is only $14.76 \%$, against a provincial average of $21.20 \%$. And, while ICT gross output of the city corresponds to $33 \%$ of the total in the province, the value-added generated is only $27.5 \%$.

Although the competitive pressures after the international crisis have pushed this territory's private and public actors to improve their R\&D capacity (Marinov and Marinova, 2012; Zhou, 2013), whether such efforts have produced results in climbing the technological ladder still has to be verified. According to the 2016 DSTGG Innovation Index, the 13 ICT STs in Dongguan appear to perform 
better than non-ICT. However, this higher ranking of ICT-specialized towns may depend on the better quality of innovation processes as well as on their mere economic size (GDASS, 2017). The empirical analysis that follows will help in better qualifying the positioning of this group of towns.

\section{Empirical analysis}

In this section we wish to test the relationship between ICT certified specialization and innovative performances on the one hand and a number of indicators for social and human development on the other.

\subsection{ICT and innovation: variables and model}

\subsubsection{Dependent variables and modelling}

We proxied the innovative capacity of each town for each year with the number of patent applications $^{8}$.

We collected data on two types of patents: those issued domestically by the State Intellectual Property of the Popular Republic of China (SIPO) and those recognized by the European Patent Office $(\mathrm{EPO})^{9}$.

The figures for patent applications recorded on SIPO and EPO across the whole period are quite different in absolute terms. As can be seen cleary in Table 3, Dongguan towns display a better patenting performance on average on the domestic rather than on the European market.

Table 3. Descriptive statistics of outcomes of interest

\begin{tabular}{lllll}
\hline & Mean & Standard deviation & Min & Max \\
\hline SIPO & 437.384 & 666.7187 & 3 & 7257 \\
EPO & 2.771 & 6.997 & 0 & 117 \\
\hline
\end{tabular}

Source: authors elaborations on SIPO and EPO databases.

\footnotetext{
${ }^{8}$ Although many criticisms have emerged on the use of patenting as a proxy for innovation (see for a review Acs, Anselin \& Varga, 2002; Griliches 1990), the number of patent applications it is still largely used in the literature contributions about innovative performances at the national and local levels (see e.g. Hu and Mathews, 2008; Lee et al., 2016; Ma, Lee \& Chen, 2009).

${ }^{9}$ In particular, we interpreted national patents as a proxy of township innovation performance related to national markets and EPO patents as a proxy of the ability to innovate at the international level. The data on SIPO are available at http://www.pss-system.gov.cn/ (in Chinese), last accessed 28 October 2017. EPO applications are retrieved by the European Patent Register - https://register.epo.org/regviewer, last accessed on 20 October 2017.
} 
Both variables seem to show that the average innovative activity of the towns has been growing impressively in the last decade, as shown in Figure $2^{10}$. Both SIPO and EPO applications are almost stagnant up to the 2000s, then from 2005 they follow an exponential trend. After the Global Crisis the trajectory is more unstable, yet continues to be positive.

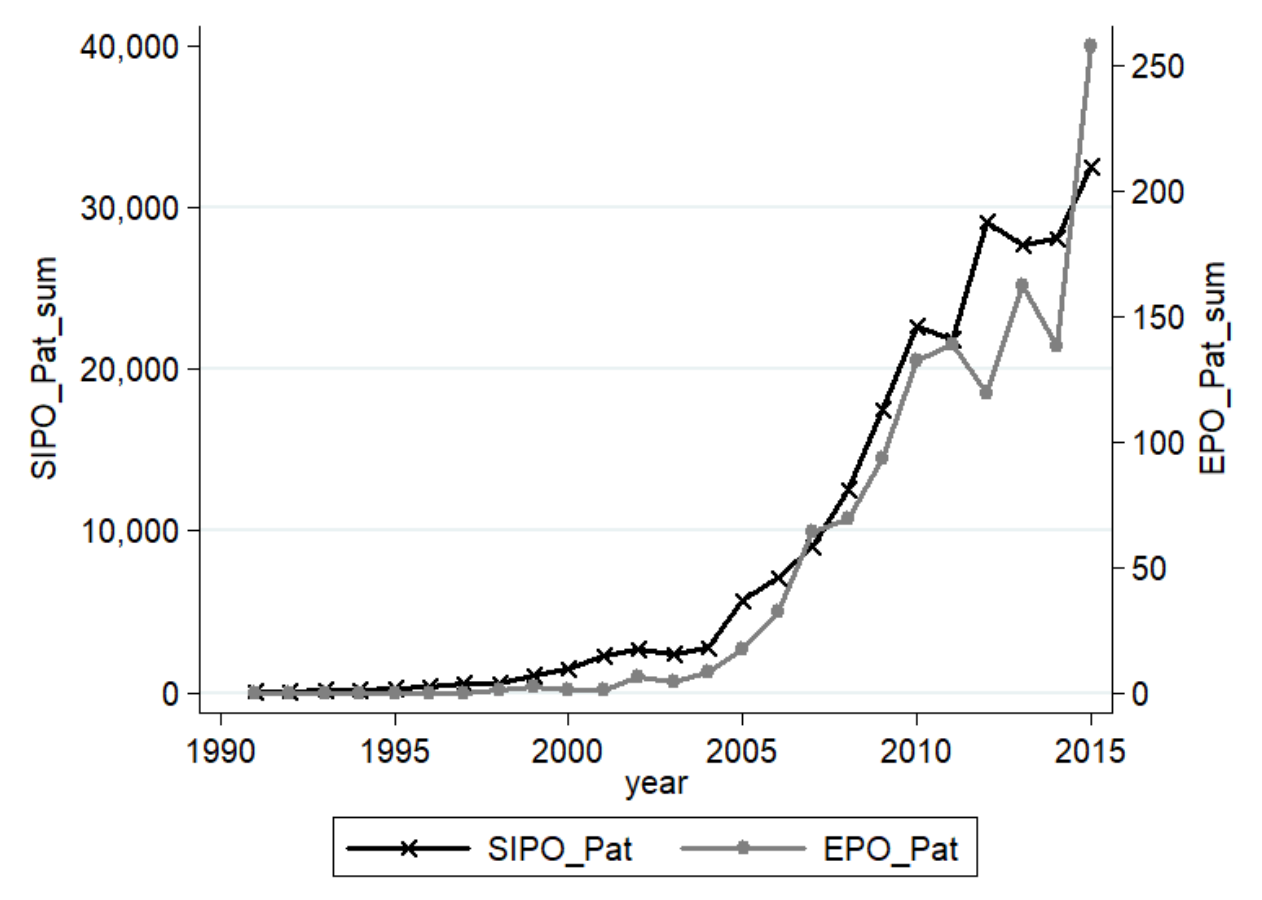

Figure 2. SIPO and EPO applications dynamics in Dongguan

Both SIPO and EPO are count variables with a largely asymmetrical distribution and substantial overdispersion (Table 3). This suggests that they should be modelled as a negative binomial function (Cameron \& Trivedi 1998; Hilbe 2011; Long \& Freese 2014). In our empirical analysis, we show the results related to SIPO patent applications ${ }^{11}$. We will use the panel version of the regression with fixed effects (Hausman, Hall \& Griliches, 1984) to exploit the longitudinal properties of our data.

\footnotetext{
${ }^{10}$ In order to show a complete picture of the innovation dynamics, we report data also outside our time-span, before 2001.

${ }^{11}$ Results on EPO patents applications, available upon requests, show weaker evidence, given the lower number of European patents (concentrated only in the last few years) that firms located in Dongguan have applied for. This also suggests a relatively low and recent exposure to the international innovation markets of such firms.
} 


\subsubsection{Independent variables}

Our main variable of interest is the dummy $I C T_{i t}$, taking value 1 when town $i$ in year $t$ has the certified status of specialization in a production related to ICT, and 0 either whether the town specialized in another sector or it is not specialized. We add to this ICT experience $_{i, t}$, measuring the number of years since official recognition by the STs program.

Further, to isolate the effect of being officially certified (in any kind of production), we introduce the dummy No $O C S_{i t}$, that takes value 1 when town $i$ at time $t$ has no officially certified specialization, and 0 otherwise.

To test our first hypothesis (H1), we use the number of foreign funded firms in the cluster (Foreign firms) as a proxy of extra-cluster linkages. Then, to test our second hypothesis (H2) we proxied the higher endowment of human capital (Dakhli and De Clercq, 2004; Lee, Nam, Lee \& Son, 2016) with the ratio of the number of graduates in secondary schools on the total population of the town $i$ at time $t-1$ (Secondary graduatest $t$ ).

We included other variables as controls to better isolate the potential effect of ICT certified specialization on innovation. At first, an economic environment may be more innovative because the production is particularly capital intensive, as suggested by the classical theory of factor endowments (Acs \& Audretsch, 1987). We use the ratio between fixed capital and employees in large firms to evaluate such effect (Capital intensity). Additionally, there might be a learning by exporting process affecting innovation, since exporters may have larger access to various forms of knowledge and innovative inputs than non-exporters (Salomon \& Shaver, 2005). For this reason, we controlled for exports at time $t-1$ (Exports Ex-1 ). Finally, we used the number of firms in the town $i$ at year $t$ (Total firms) to control for the general economic size of the town.

We summarize the variables in Table 4 and the summary statistics and the correlation table are presented in theAppendix (Tables A1 and A2) ${ }^{12}$.

\footnotetext{
${ }^{12}$ In the 2001-2015 period, and specifically in the years 2005, 2008 and 2011, some changes have occurred in the collection and organization of data in Dongguan statistical yearbooks. We account for these changes by adding
} 
Since one of our main intuitions is that ICT specialization may be associated with higher innovation levels according to its characterization, we present both the baseline specification and two models in which we study moderation effects in order to test hypotheses $\mathrm{H} 1$ and $\mathrm{H} 2$.

Table 4. Explanatory variables

\begin{tabular}{|c|c|c|}
\hline Variable & Measured dimension & Measured as \\
\hline ICT & $\begin{array}{l}\text { ICT certified specialization of the } \\
\text { township }\end{array}$ & $\begin{array}{l}\text { Dummy variable }=1 \text { if the township is } \\
\text { specialized in ICT and } 0 \text { otherwise }\end{array}$ \\
\hline No OCS & $\begin{array}{l}\text { The township is not/is a specialized } \\
\text { town }\end{array}$ & $\begin{array}{l}\text { Dummy variable }=1 \text { if the township has } \\
\text { no certified specialization and } 0 \\
\text { otherwise }\end{array}$ \\
\hline ICT experience & Length of the policy program & $\begin{array}{l}\text { Years from ICT specialization officially } \\
\text { recognition }\end{array}$ \\
\hline Capital intensity & $\begin{array}{l}\text { Source of innovation from capital- } \\
\text { intensive production }\end{array}$ & $\begin{array}{l}\text { Ratio between fixed assets }(10,000 \\
\text { yuan) and number of employees in large } \\
\text { enterprises }\end{array}$ \\
\hline Total firms & Size of the economy & Number of firms \\
\hline Foreign firms & $\begin{array}{l}\text { Source of innovation from spillover } \\
\text { by foreign firms }\end{array}$ & Number of foreign funded firms \\
\hline Export $_{\mathrm{t}-1}$ & $\begin{array}{l}\text { Sources of innovation from } \\
\text { learning by exporting }\end{array}$ & $\begin{array}{l}\text { Value }(10,000 \text { US \$) of the exports in the } \\
\text { year before the observed one }\end{array}$ \\
\hline Secondary graduatest-1 & $\begin{array}{l}\text { Sources of innovation from human } \\
\text { capital endowment }\end{array}$ & $\begin{array}{l}\text { Number of graduated from secondary } \\
\text { school on the population in the year } \\
\text { before the observed one. }\end{array}$ \\
\hline
\end{tabular}

\subsection{ICT and innovation: results and discussion}

The first column of Table 5 reports the baseline results. Having an officially recognized specialization in the ICT production per se does not help townships increase their innovative performances. On the contrary, such townships perform worse than others do. This can be due to the fact that the capacity of ICT clusters to boost innovation is heavily affected by the positioning of the cluster within global value chains. Our results confirm that Dongguan ICT clusters still deal with the simplest tasks in the production process and are mainly related to the labor-intensive production of electronic appliances and other ICT goods. This means that they mainly act as downstream suppliers for multinational firms to meet national demand (Cheng \& Peyiu, 2001; Zhou, 2013; Zhou et al., 2011).

dummies to the model that account for them from the moment in time they occur. These variables do not have an economic interpretation but ensure that we clean the data from the technical changes. 
The results show that the negative effect of the ICT specialization is not due to a negative effect of the STs program per se. In fact, the negative effect of not being part of the STs program on the number of SIPO applications suggests that the institutional setting promoting innovation described in section 4 actually helps in terms of township's the innovative capacity to grow. Domestic market innovation outputs seem to profit from a better-educated social environment, likely reflected in the larger availability of human capital at a local level. They also appear to gain from foreign resources via a process of learning by exporting. On the contrary, while the overall size of the economy (proxied by the number of total firms) can positively affect innovation, foreign firms appear to contribute to it negatively. This might be in line with a labor-intensive and relatively lowtechnology characterization of Dongguan production. In fact, in cases like these, other contributions have shown that overseas firms tend to innovate and patent less than domestic firms (Fu \& Gong, 2011).

Table 5. Effects of ICT on SIPO - negative binomial conditional fixed effect regressions

\begin{tabular}{|c|c|c|c|}
\hline & \multirow[b]{2}{*}{$\begin{array}{c}\text { Baseline model } \\
\text { (1) }\end{array}$} & \multicolumn{2}{|c|}{ Models with interactions } \\
\hline & & $\begin{array}{c}\text { Secondary graduates } \\
\text { (2) }\end{array}$ & $\begin{array}{c}\text { Foreign firms } \\
\text { (3) }\end{array}$ \\
\hline ICT & $\begin{array}{l}-0.190 * \\
(-1.95)\end{array}$ & $\begin{array}{c}-0.683 * * * \\
(-4.33)\end{array}$ & $\begin{array}{c}-0.389 * * \\
(-2.51)\end{array}$ \\
\hline No OCS & $\begin{array}{c}-0.267 * * * \\
(-4.12)\end{array}$ & $\begin{array}{c}-0.221 * * * \\
(-3.44)\end{array}$ & $\begin{array}{c}-0.271 * * * \\
(-4.23)\end{array}$ \\
\hline ICT experience & $\begin{array}{l}0.011 \\
(1.06)\end{array}$ & $\begin{array}{l}0.012 \\
(1.06)\end{array}$ & $\begin{array}{l}0.012 \\
(1.11)\end{array}$ \\
\hline Capital intensity & $\begin{array}{l}0.001 \\
(0.59)\end{array}$ & $\begin{array}{l}0.001 \\
(0.51)\end{array}$ & $\begin{array}{l}0.001 \\
(0.55)\end{array}$ \\
\hline Total firms & $\begin{array}{c}0.000005 * * * \\
(2.93)\end{array}$ & $\begin{array}{c}0.000005 * * * \\
(2.95)\end{array}$ & $\begin{array}{c}0.000005^{* * * *} \\
(2.82)\end{array}$ \\
\hline Export 1 & $\begin{array}{c}0.0000005^{* *} \\
(2.37)\end{array}$ & $\begin{array}{c}0.0000005^{* *} \\
(2.18)\end{array}$ & $\begin{array}{c}0.0000005^{* *} \\
(2.34)\end{array}$ \\
\hline Foreign firms & $\begin{array}{c}-0.0003 * \\
(-1.93)\end{array}$ & $\begin{array}{c}-0.0003^{* *} \\
(-2.02)\end{array}$ & $\begin{array}{c}0.0004 * \\
(1.66)\end{array}$ \\
\hline Secondary graduatest-1 & $\begin{array}{c}11.46^{* * * *} \\
(3.64)\end{array}$ & $\begin{array}{c}7.462 * * \\
(2.29)\end{array}$ & $\begin{array}{c}11.14 * * * \\
(3.55)\end{array}$ \\
\hline ICT*(Secondary graduatest-1) & & $\begin{array}{c}14.02 * * * \\
(4.17)\end{array}$ & \\
\hline ICT*(Foreign firms) & & & $\begin{array}{l}0.000353 * \\
\quad(1.66)\end{array}$ \\
\hline Constant & $\begin{array}{c}0.982 * * * \\
\quad(7.46)\end{array}$ & $\begin{array}{l}1.110 * * * \\
(8.35)\end{array}$ & $\begin{array}{c}1.058 * * * \\
(7.68)\end{array}$ \\
\hline
\end{tabular}




\begin{tabular}{lccc}
\hline Effect of change in statistics & Yes & Yes & Yes \\
Town fixed effects & Yes & Yes & Yes \\
$\mathrm{N}$ & 479 & 479 & -2721.1 \\
$\mathrm{Ll}$ & -2722.5 & -2714.4 & 5522.4 \\
$\mathrm{Bic}$ & 5519 & 5509 & 5468.2 \\
Aic & 5469 & 5454.7 & 1203.0 \\
chi2_c & 1191.6 & 1279.5 & \\
\hline Significance. $* 10 \%, * * 5 \%, * * * 1 \%$ Standard error in parenthesis.
\end{tabular}

Significance: $* 10 \%, * * 5 \%, * * * 1 \%$. Standard error in parenthesis.

Results related to our specific hypotheses $\mathrm{H} 1$ and $\mathrm{H} 2$ are reported in column 2 and 3, where we interact ICT with the dimensions of human capital and foreign linkages. As we are in a non-linear framework, their interpretation is not straightforward and is better supported by visual representations of the effects (Rubini, Pollio \& Di Tommaso, 2017; Williams, 2012), which we show in Figure 3. It is clear that both the percentage of secondary graduates and the number of foreign firms display some threshold values for which the ICT specialization pays in terms of innovation versus non-ICT clusters. With regards to human capital, ICT clusters have a chance at performing significantly better than non-ICT clusters if the ratio of secondary graduates is above 0.05 . As for the number of foreign firms, the results from the interaction show that in the presence of a sufficient number of foreign firms (above 1100), ICT clusters perform better than others. In other words, the higher chances of innovating within ICT, highlighted in section 2.2, seem to mitigate the attitude of foreign companies against patenting in China.

Thus both hypotheses $\mathrm{H} 1$ and $\mathrm{H} 2$ are confirmed.

Figure 3. Moderation effects on ICT
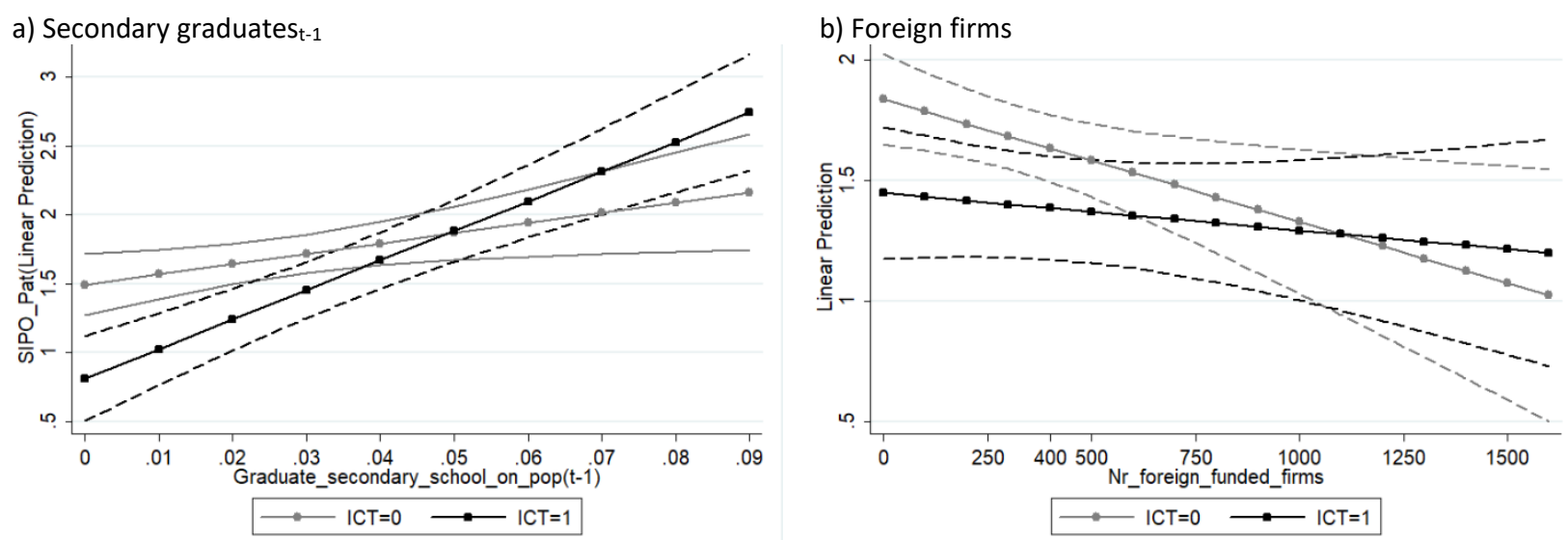
These results are quite significant in comprehending the future prospects in terms of policies for technological innovation of the ICT clusters in Dongguan. At present, in fact, these clusters have not yet reached those thresholds, as shown by the distributions of the variables and the comparison of ICT group with other Specialized towns (Figure 4).

Figure 4. Distribution of ICT vs non-ICT towns over interaction variables, year 2016

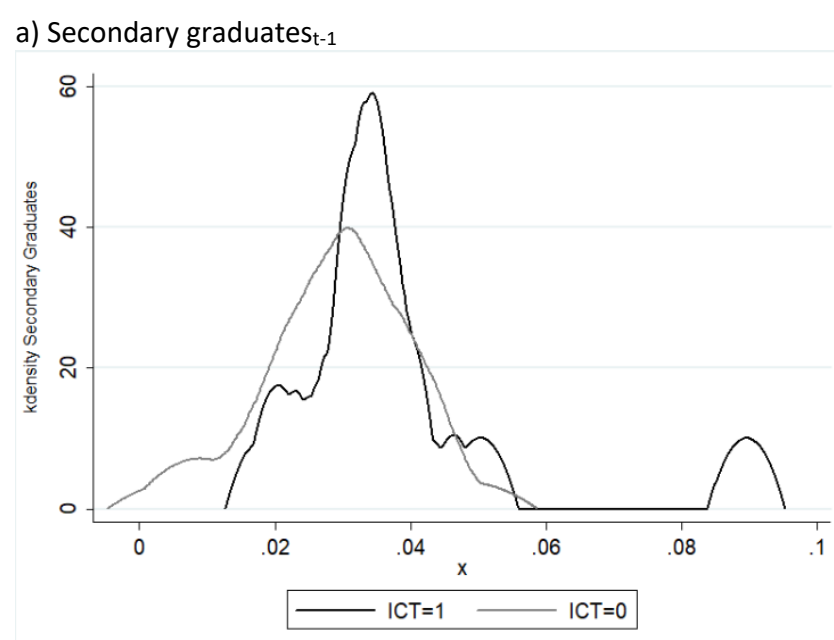

b) Foreign firms

\section{Wilcoxon test z-value: 0.2146}

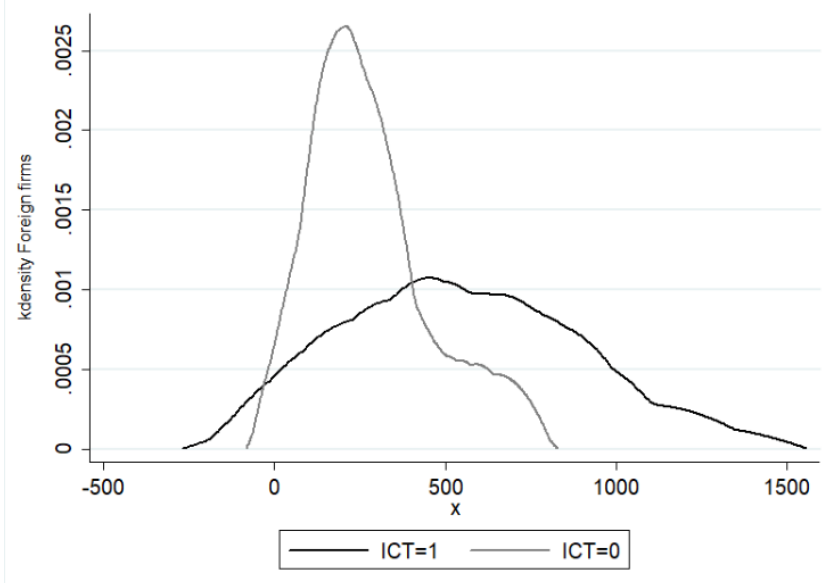

On the one hand, both the presence of foreign firms and, although to a lesser extent, the intensity of human capital are actually higher in ICT clusters compared to non-ICT STs ${ }^{13}$. However, ICT STs still display, on average, a far lower value than the thresholds identified in Figure 4. Such evidence suggests that, while there might be some potential gains coming from the specialization in ICT for Dongguan clusters under certain conditions, more has still to be done to reach them.

\subsection{ICT and socially sustainable development: variables and model}

\subsubsection{Dependent variables and modelling}

The second part of our empirical analysis deals with hypotheses $\mathrm{H} 3$ and $\mathrm{H} 4$.

Here we measure the possible impact of ICT recognized specialization on three tailored indices of social sustainability. In doing so, we take into account the complexity and the multi-

\footnotetext{
${ }^{13}$ In the case of foreign firms, the difference is also confirmed by the significance of the Wilcoxon Test, which compares the distributions of the two samples non-parametrically to assess whether there are statistical differences (Wilcoxon, 1945; Pollio, Barbieri, Rubini \& Di Tommaso, 2016).
} 
dimensionality which characterize the concepts of social sustainability and social sustainable development. Each index is summarized together with the single dimensions included in Table 6.

1) "Townships Social Development Index" (TOSDI). This is a composite indicator built on variables traditionally included in the Human Development Index (HDI). Given the lack of information on life expectancy and year of schooling for Dongguan, it was not possible to exactly replicate the variables used for the HDI. However, recent contributions by the international organizations have assumed that human development should be measured not only in terms of quantity, such as the number of years a person lives or the number of years of education, but also in terms of quality and, that is, whether people could really gain competencies from education, the quality of health assistance they receive throughout their lives and so on (UNDP, 2018). Consequently, other indicators related to the social supply of health and education have been introduced to measure the quality of development. Regarding education, the number of graduates in primary school per capita (Primary Graduates - GrP) and the number of graduates in secondary school per capita (Secondary Graduates - GrS) are summarized in an additive index. Then, we include a measure of quality of health, as per capita number of beds in health institutions (Beds) already used in international statistics to assess the quality of health (UNDP, 2018) ${ }^{14}$. Finally, TOSDI index includes per capita GDP (GDPpc) as a proxy for the economic status.

2) Basic needs-Opportunities-Networks Index (BON). When acknowledging the various dimensions of social sustainability, Littig and Grießler (2005) suggest that three sets of indicators should be taken into consideration: (1) basic needs and quality of life; (2) social justice ad equal opportunity; and, (3) social coherence and integration within social networks. On the basis of these, we have built BON, a composite index aimed at placing the three aspects altogether. To proxy basic needs we used per capita GDP $(G D P p c)$ or alternatively, we considered the number of graduates in

\footnotetext{
${ }^{14} \mathrm{~A}$ second indicator that measures quality of health is the per capita number of physicians. Although this information is available in our data, we could not include it in the index due to high correlation with the per capita number of beds.
} 
primary school on population $(G r P)^{15}$ based on the availability of data. In reference to social justice, we introduced a measure of social inequality which is particularly relevant in China, i.e. the divide between urban and rural population, proxied in our case as the ratio between urban and rural residents (Urban/rural ratio - URr). Indeed, rural residents are generally acknowledged to suffer from unequal access to opportunities with respect to their urban peers (Jian, Chan, Reidpath \& Xu, 2010; Treiman, 2012; Zhang, 2017). In this sense, a larger proportion of urban residents with respect to rural residence permit holders means that a large stratum of population has access to better and a wider range of social services. Finally, to proxy intra-cluster network, we employed the number of specialized markets in the township (Specialized Markets - SM) which are confined areas where usually small and medium producers involved in the manufacturing of similar products gather. Such social institutions have already been used as a proxy of collective action and linkages between economic and social actors in the Chinese framework (Bellandi \& Lombardi, 2012; Wang \& Mei, 2009).

3) Socioeconomic Sustainability Index (SES). This index aims at bridging aspects of long-term sustainability and equity, in both economic and in social terms. To build it we have adopted and combined several measures used in the UNDP dashboard on socioeconomic sustainability (UNDP, 2018). The first is related to government balance savings, measured in our case as the ratio between local revenues and expenditure (Revenue/Expenditure ratio - REr). While this is a typical indicator of economic sustainability, it can contribute to qualify social sustainability as it represents the relation between present and future welfare and social public provision spending. Secondly, we used skilled workers number, measured as the ratio between the workers having at least a Master's Degree in R\&D departments of firms against the total number of employees (Skilled/Workers Ratio$S W r)$. We included this indicator to evaluate whether the economic environment is able to attract better educated workers, as well as to potentially stimulate better education attainments for larger

\footnotetext{
${ }^{15}$ In the results, we only discuss the evidence related to the index containing graduates in primary education. However, results when per capita GDP is included are similar and can be interpreted in the same way, in particular with respect to our hypotheses.
} 
strata of population. Finally, the social sustainability aspect in UNDP measures looks carefully at multi-dimensional inequalities. Following this line, we introduced an indicator measuring another of the most important phenomena of the economic and social divide in the Chinese context and, that is, migration. While studying the relationship between clustering and social sustainability, in the case of China it is necessary to consider the role that migration flows have in the economic development process of coastal areas (Di Tommaso et al., 2013). On the one hand, the massive inflow of workers coming from inner areas of the country has allowed the coastal region to count on a vast amount of low-cost workforce that has represented its initial competitive advantage. On the other, due to the specific household registration system of the country, called the 'hukou'16 (Song, 2014), migrant workers have different access to social services and economic rights, and often suffer from social exclusion (Combes, Démurger, Li \& Wang, 2019; Chen, Lu \& Zhong, 2015; Zhan, 2011). This phenomenon has been observed also in the case of Dongguan (Luo \& Zhu, 2015). For this reason, we included the Registered/Resident ratio which compares the number of registered population in the township, who have a resident hukou, to the total number of resident population and, that is, those living in the township for at least 6 months. A higher number of people having registered status means larger strata of population having access to social services and economic rights.

For TOSDI and BON indices, our data range between 2006 and 2016. Conversely, due to limits to data availability, the observation of SES index is restricted to the 2010-2016 range ${ }^{17}$. We report the summary statistics and the correlations for the original variables in the Appendix (Table A3).

Table 6. Dimensions of the social sustainability indexes

\begin{tabular}{|l|l|l|c|}
\hline Index & Dimension & Component & Dimension index* \\
\hline \multirow{3}{*}{$T O S D I=\sqrt[3]{E C * E d u * H e a}$} & Economic Status $(E C)$ & Per capita GDP $(G D P p c)$ & $E C=S T D(G D P p c)$ \\
\cline { 2 - 3 } & Education $(E d u)$ & Primary graduates $(G r P)$ & \multirow{2}{*}{$E d u=\frac{[S T D(G r P)+S T D(G r S)]}{2}$} \\
\cline { 2 - 3 } & & Secondary graduates $(G r S)$ & \\
\hline
\end{tabular}

\footnotetext{
${ }^{16}$ The hukou is the residence permit for Chinese citizens. It is related to the birthplace of each person, and is very difficult to change.

${ }^{17}$ The indices are built up following the same standardization and aggregation methodology used to build the HDI (UNDP, 2016). All the variables included in the three indices are standardized via minmax scaling. The final indices result as geometrical means of their dimension indices.
} 


\begin{tabular}{|c|c|c|c|}
\hline & Health $(\mathrm{Hea})$ & Number of beds (Beds) & $H e a=S T D($ Beds $)$ \\
\hline \multirow{4}{*}{$B O N_{k}=\sqrt[3]{B N_{k} * O p * N e}$} & $\begin{array}{l}\text { Basic Needs }- \text { with } \\
\text { Primary graduates } \\
\left(B N_{E D U}\right)\end{array}$ & Primary graduates $(G r P)$ & $B N=S T D(G r P)$ \\
\hline & $\begin{array}{l}\text { Basic Needs - with } \\
\text { GDP }\left(B N_{G D P}\right)\end{array}$ & Per capita GDP $(G D P p c)$ & $B N=S T D(G D P p c)$ \\
\hline & Opportunities $(O p)$ & Urban/Rural ratio $(U R r)$ & $O p=S T D(U R r)$ \\
\hline & Networks $(\mathrm{Ne})$ & Specialized Markets (SM) & $N e=S T D(S M)$ \\
\hline \multirow{3}{*}{$S E S=\sqrt[3]{S P S * S k R * H l R}$} & $\begin{array}{l}\text { Social provisions } \\
\text { sustainability }(S P S)\end{array}$ & $\begin{array}{l}\text { Revenue/Expenditure ratio } \\
(R E r)\end{array}$ & $S P S=S T D(R E r)$ \\
\hline & Better education $(B E)$ & $\begin{array}{lll}\text { Skilled } & \text { Workers } & \text { Ratio } \\
(S W r) & & \end{array}$ & $B E=S T D(S W R)$ \\
\hline & $\begin{array}{l}\text { Hukou-linked Rights } \\
(H I R)\end{array}$ & $\begin{array}{l}\text { Registered/Resident ratio } \\
(R R r)\end{array}$ & $H l R=S T D(R R r)$ \\
\hline
\end{tabular}

*STD $=$ Standardization via minmax scaling.

Social sustainability was studied as a function of some variables of interest in a linear fixed effects panel model with robust standard errors-

\subsubsection{Independent variables}

We have already discussed the meaning of the variables ICT, experience ICT and No OCS in section 5.1.2. In particular, experience ICT is the variable of interest to test hypothesis $\mathrm{H} 3$.

As for hypothesis $\mathrm{H} 4$, we include variables related to technological innovation and economic dynamism in the regression. In particular, we proxied innovation with the cumulative number of patent applications in the domestic market (cumulative SIPO) using1991 as the base year. Additionally, we control for the number of Chinese and foreign firms (Total firms).

To control for possible effects due to export-led development and the international exposure of the territory on social sustainability, we included the ratio between Exports and GDP (Exports/GDP ratio) and the ratio between foreign and local firms (Foreign/local firms ratio) of the township.

Finally, we control for township Cumulative net migration (as the cumulative difference between immigrants and emigrants) using 1991 as the base year, to measure the amount of migrant population that gradually settle in the township. This can proxy the degree to which township 
community tends to stabilize and generate the preconditions for social cohesion, and is particularly relevant when assessing the effects on social sustainability measures that incorporate inequality dimensions related to the hukou status (SES and BON indices). All independent variables are summarized in Table 7, while summary statistics and correlation are in Tables A4 and A5 in the Appendix.

To assess whether these aspects can foster social sustainable development in particular in the context of ICT clusters, next to the base regression we have added models with interactions between ICT and SIPO, Exports/GDP ratio and Foreign/Local firms ratio. ${ }^{18}$

Table 7. Explanatory variables

\begin{tabular}{|c|c|}
\hline Variable & Measured as \\
\hline \multicolumn{2}{|c|}{ Main variables of interest } \\
\hline ICT & Dummy variable $=1$ if the township is specialized in ICT and 0 otherwise \\
\hline ICT experience & Years from official recognition in ICT specialization \\
\hline No OCS & Dummy variable $=1$ if the township has no certified specialization and 0 otherwise \\
\hline \multicolumn{2}{|l|}{ Other controls } \\
\hline Cumulative SIPO & Cumulative number of SIPO patent applications by the town (starting year 1991) \\
\hline Total firms & Total number of firms in the townships \\
\hline Exports/GDP ratio & Ratio between the value of township's Exports and GDP \\
\hline Foreign/Local firms ratio & $\begin{array}{l}\text { Ratio between the number of foreign funded firms and the number of domestic } \\
\text { firms }\end{array}$ \\
\hline Cumulative net migration & $\begin{array}{l}\text { Cumulative value of net migration (as the difference between immigrants and } \\
\text { emigrants) in the town (starting year 1991) }\end{array}$ \\
\hline
\end{tabular}

\subsection{ICT and social sustainability: results and discussion}

The main results related to $\mathrm{H} 3$ and $\mathrm{H} 4$ are reported in Table 8. We first examine the results related to TOSDI and BON indices ${ }^{19}$. When looking at the baseline models (columns 1 and 2), while non-specialized towns clearly perform worse than others, ICT specialization does not show better returns. On the contrary, it can generate even worse results in terms of social development. However,

\footnotetext{
${ }_{18}$ Apart from the interaction with cumulative SIPO, which we always cite, for the sake of clarity we only report results for regressions with interactions when the latter are significant.

${ }^{19}$ The results on the SES index need to be evaluated with some caution, in the light of the limited time span for which it was possible to build up the indicator as this correspond to less than half the observations for other indices.
} 
when we consider possible learning processes proxied by experience in policy support in ICT, we find positive effects which are able to counterbalance the negative or null values of the ICT dummies within few years.

This might suggest that policies aimed at stimulating collective actions and social networks in the context of fast-growing sector as ICT are indeed more effective in promoting social sustainability than in others ${ }^{20}$. 
Table 8. ICT and social sustainability indicators

\begin{tabular}{|c|c|c|c|c|c|c|c|c|c|c|}
\hline & \multirow{2}{*}{\multicolumn{2}{|c|}{ Baseline models }} & \multicolumn{5}{|c|}{ Models with interactions } & \multirow{3}{*}{$\begin{array}{c}\text { Baseline } \\
\text { model } \\
(8) \\
\text { SES } \\
\end{array}$} & \multirow{2}{*}{\multicolumn{2}{|c|}{ Models with interactions }} \\
\hline & & & Inn & ation & For & n linkages/exp & ure & & & \\
\hline & $\begin{array}{c}\text { (1) } \\
\text { TOSDI }\end{array}$ & $\begin{array}{c}(2) \\
\text { BONEDU }\end{array}$ & $\begin{array}{c}\text { (3) } \\
\text { TOSDI }\end{array}$ & $\begin{array}{c}\text { (4) } \\
\text { BONEDU }\end{array}$ & $\begin{array}{c}\text { (5) } \\
\text { TOSDI }\end{array}$ & $\begin{array}{c}\text { (6) } \\
\text { TOSDI }\end{array}$ & $\begin{array}{c}\text { (7) } \\
\text { BONEDU }\end{array}$ & & $\begin{array}{c}\text { (9) } \\
\text { SES }\end{array}$ & $\begin{array}{l}\text { (10) } \\
\text { SES }\end{array}$ \\
\hline ICT & $\begin{array}{c}-0.0426 \\
(-1.42)\end{array}$ & $\begin{array}{c}-0.0703 * * \\
(-2.34)\end{array}$ & $\begin{array}{l}-0.0098 \\
(-0.30)\end{array}$ & $\begin{array}{l}-0.0225 \\
(-0.66)\end{array}$ & $\begin{array}{c}-0.1050^{* *} \\
(-2.70)\end{array}$ & $\begin{array}{c}-0.0640^{*} \\
(-1.98)\end{array}$ & $\begin{array}{c}-0.0971 * * \\
(-2.38)\end{array}$ & $\begin{array}{c}-0.0693 * * * \\
(-3.86)\end{array}$ & $\begin{array}{c}-0.0573 * * * \\
(-2.84)\end{array}$ & $\begin{array}{c}-0.0251 \\
(-0.92)\end{array}$ \\
\hline ICT Experience & $\begin{array}{c}0.0119 * * \\
(2.56)\end{array}$ & $\begin{array}{c}0.0140 * * * \\
(3.44)\end{array}$ & $\begin{array}{c}0.0126 * * * \\
(2.80)\end{array}$ & $\begin{array}{c}0.0150^{* * * *} \\
(4.03)\end{array}$ & $\begin{array}{c}0.0128^{* * *} \\
(2.83)\end{array}$ & $\begin{array}{c}0.0122 * * \\
(2.65)\end{array}$ & $\begin{array}{c}0.0144 * * * \\
(3.44)\end{array}$ & $\begin{array}{r}0.0105 \\
(1.28)\end{array}$ & $\begin{array}{c}0.0114 \\
(1.30)\end{array}$ & $\begin{array}{c}0.00728 \\
(0.89)\end{array}$ \\
\hline No OCS & $\begin{array}{c}-0.0624 * * * \\
(5.59)\end{array}$ & $\begin{array}{c}-0.0700 * * * \\
\quad(-4.42)\end{array}$ & $\begin{array}{c}-0.0536^{* * *} \\
(4.58)\end{array}$ & $\begin{array}{c}-0.0574 * * * \\
\quad(-3.41)\end{array}$ & $\begin{array}{c}-0.0575^{* * * *} \\
(4.94)\end{array}$ & $\begin{array}{c}-0.0610^{* * *} \\
(5.47)\end{array}$ & $\begin{array}{c}-0.0682 * * * \\
(-4.32)\end{array}$ & $\begin{array}{c}-0.0385^{* * *} \\
(3.69)\end{array}$ & $\begin{array}{c}-0.0378^{* * *} \\
(3.53)\end{array}$ & $\begin{array}{c}-0.0416^{* * *} \\
(3.93)\end{array}$ \\
\hline Cumulative SIPO & $\begin{array}{c}0.000004 \\
(1.49)\end{array}$ & $\begin{array}{c}0.000002 \\
(0.52)\end{array}$ & $\begin{array}{c}0.000010^{* * *} \\
(2.93)\end{array}$ & $\begin{array}{l}0.000010^{* *} \\
\quad(2.43)\end{array}$ & $\begin{array}{l}0.000005^{*} \\
(1.72)\end{array}$ & $\begin{array}{c}0.000004 \\
(1.57)\end{array}$ & $\begin{array}{l}0.000002 \\
(0.57)\end{array}$ & $\begin{array}{c}0.000001 \\
(0.38)\end{array}$ & $\begin{array}{c}0.000003 \\
(0.94)\end{array}$ & $\begin{array}{c}0.000002 \\
(0.84)\end{array}$ \\
\hline Exports/GDP ratio & $\begin{array}{r}-0.0907 \\
(-0.58)\end{array}$ & $\begin{array}{l}-0.0515 \\
(-0.48)\end{array}$ & $\begin{array}{c}-0.08 \\
(-0.52)\end{array}$ & $\begin{array}{c}-0.0350 \\
(-0.36)\end{array}$ & $\begin{array}{l}-0.173 \\
(-0.94)\end{array}$ & $\begin{array}{c}-0.0843 \\
(-0.54)\end{array}$ & $\begin{array}{c}-0.0434 \\
(-0.42)\end{array}$ & $\begin{array}{r}-0.0821 \\
(-0.54)\end{array}$ & $\begin{array}{c}-0.0678 \\
(-0.43)\end{array}$ & $\begin{array}{c}-0.0219 \\
(-0.13)\end{array}$ \\
\hline Total Firms & $\begin{array}{c}0.000001 * * * \\
(2.82)\end{array}$ & $\begin{array}{c}0.000001 \\
(1.67)\end{array}$ & $\begin{array}{l}0.000001^{* *} \\
(2.66)\end{array}$ & $\begin{array}{c}0.000001 \\
(1.56)\end{array}$ & $\begin{array}{c}0.000001 * * * \\
(2.82)\end{array}$ & $\begin{array}{c}0.000001^{* *} \\
(2.72)\end{array}$ & $\begin{array}{c}0.000001^{*} \\
(1.71)\end{array}$ & $\begin{array}{c}-0.0000002 \\
(-0.39)\end{array}$ & $\begin{array}{c}-0.0000001 \\
(-0.21)\end{array}$ & $\begin{array}{c}-0.0000004 \\
(-0.97)\end{array}$ \\
\hline Foreign/Local firms ratio & $\begin{array}{l}0.0330 \\
(0.61)\end{array}$ & $\begin{array}{l}0.154 \\
(1.60)\end{array}$ & $\begin{array}{l}0.0403 \\
(0.76)\end{array}$ & $\begin{array}{l}0.164 \\
(1.64)\end{array}$ & $\begin{array}{l}0.0133 \\
(0.24)\end{array}$ & $\begin{array}{c}-0.0036 \\
(-0.07)\end{array}$ & $\begin{array}{l}0.108 \\
(1.18)\end{array}$ & $\begin{array}{c}-2.970 * * * \\
(-2.98)\end{array}$ & $\begin{array}{c}-2.836 * * * \\
(-3.04)\end{array}$ & $\begin{array}{c}-2.930 * * * \\
(-2.99)\end{array}$ \\
\hline Cumulative net migration & $\begin{array}{c}0.000006^{* * *} \\
(3.38)\end{array}$ & $\begin{array}{l}0.000005^{* *} \\
(2.29)\end{array}$ & $\begin{array}{l}0.000005^{* *} \\
(2.63)\end{array}$ & $\begin{array}{c}0.000002 \\
(1.60)\end{array}$ & $\begin{array}{c}0.000006^{* * *} \\
(3.40)\end{array}$ & $\begin{array}{c}0.000006^{* * *} \\
(3.33)\end{array}$ & $\begin{array}{c}0.000005^{* *} \\
(2.25)\end{array}$ & $\begin{array}{l}0.000004 \\
(0.84)\end{array}$ & $\begin{array}{l}0.000004 \\
(0.74)\end{array}$ & $\begin{array}{l}0.000004 \\
(0.78)\end{array}$ \\
\hline ICT*(Cumulative SIPO) & & & $\begin{array}{c}-0.000007^{* *} \\
(-2.59)\end{array}$ & $\begin{array}{c}-0.000010^{* * *} \\
(-3.99)\end{array}$ & & & & & $\begin{array}{c}-0.000002 \\
(-0.67)\end{array}$ & \\
\hline ICT*(Exports/GDP ratio) & & & & & $\begin{array}{c}0.273^{* *} \\
(2.18)\end{array}$ & & & & & $\begin{array}{l}-0.201^{*} \\
(-1.98)\end{array}$ \\
\hline ICT*(Foreign/Local firms ratio) & & & & & & $\begin{array}{c}0.754 * * * \\
(2.82)\end{array}$ & $\begin{array}{l}0.946^{*} \\
(1.82)\end{array}$ & & & \\
\hline Constant & $\begin{array}{c}0.160 * * * \\
\quad(4.63)\end{array}$ & $\begin{array}{c}0.237 * * * \\
(8.58)\end{array}$ & $\begin{array}{c}0.157 * * * \\
(4.74)\end{array}$ & $\begin{array}{c}0.220 * * * \\
(8.17)\end{array}$ & $\begin{array}{c}0.176^{* * * *} \\
(4.76)\end{array}$ & $\begin{array}{c}0.160 * * * \\
(4.66)\end{array}$ & $\begin{array}{c}0.235^{* * * *} \\
(8.83)\end{array}$ & $\begin{array}{c}0.215^{* * *} \\
(4.68)\end{array}$ & $\begin{array}{c}0.203 * * * \\
(4.03)\end{array}$ & $\begin{array}{c}0.213 * * * \\
(4.76)\end{array}$ \\
\hline Townships Fixed effects & Yes & Yes & Yes & Yes & Yes & Yes & Yes & Yes & Yes & Yes \\
\hline Number of years observed & 15 & 15 & 15 & 15 & 15 & 15 & 15 & 7 & 7 & 7 \\
\hline $\mathrm{N}$ & 479 & 480 & 479 & 480 & 479 & 479 & 480 & 224 & 224 & 224 \\
\hline Adjuster R2 & 0.688 & 0.508 & 0.702 & 0.536 & 0.698 & 0.691 & 0.512 & 0.283 & 0.282 & 0.288 \\
\hline $\mathrm{F}$ & 36.71 & 19.46 & 38.88 & 25.89 & 38.69 & 34.97 & 18.29 & 12.91 & 11.45 & 13.29 \\
\hline$p$-value & 0.00 & 0.00 & 0.00 & 0.00 & 0.00 & 0.00 & 0.00 & 0.00 & 0.00 & 0.00 \\
\hline
\end{tabular}


Interestingly, there is no clear effect of innovation (Cumulative SIPO) with linkages to foreign environment (Exports/GDP ratio and Foreign/Local firms ratio) per se, while the size of the economy, as represented by total firms, is likely to positively affect social sustainability. This is particularly pertinent when income dimensions are taken into consideration (as in TOSDI). Additionally, stabilizing communities, represented by the cumulative net migration values, appear to have positive effects on social outcomes.

Columns 3 to 7 of the table analyze, by means of interactive terms, whether innovative performances and international exposure have specific effects within the context of ICT specialization. When exploring the interactions with cumulative SIPO applications on the TOSDI index (column 3), which includes aspects of social sustainability more connected to the supply of social provisions and economic factors, we find that innovation can still play a role in improving social sustainability. However, this is not confirmed when evaluating social sustainability with a more multidimensional and heterogeneous indicator such as BON, as the sum of the interactive term and the single variable included is (slightly) negative. The results related to international exposure (columns 5 to 7) are more coherent and point towards a positive, when significant, effect of such linkages on social outcomes, particularly in ICT clusters.

Columns 8 to 10 show the results for the SES index. In this case, while we still observe a negative relation with ICT, there is no effect of ICT experience and similarly innovation, either by itself or interacted, is not able to generate positive effects. However, we must acknowledge that, in the case of SES index, we only observe a limited time span (2010-2016). This might be relevant when analyzing the variables that are connected with the evolution in time, such as ICT experience, Cumulative SIPO and Cumulative net migration, as, by construct, they show less variability than in larger time spans. Finally, we find that the variables representing the clusters' linkages to foreign forces, in this case, impact social sustainability negatively. In order to comment this result properly, we need to note that the index is potentially aimed at capturing mid-term social sustainability aspects. In light of this, the negative coefficients associated with the foreign/local firms ratio per se and with 
the interaction between ICT and exports may signal that some obstacles, in terms of social sustainable development in the long term, occur as a consequence of international exposure, in particular with respect to the export propensity of ICT clusters. This specific result would be in line with the literature underlying that ICT clusters often emerge as an exports hub in developing countries, where production is intended for other locations, while not reaping the benefits of adopting ICT also for the purposes of social development (Steinmueller, 2001).

All this said, and given the caution in the interpretation of the results related to SES index, our evidence points to confirm $\mathrm{H} 3$. On the other hand, the results related to the interaction between ICT and innovation aimed at testing $\mathrm{H} 4$ points to a positive relation only with respect to TOSDI index, which is more triggered by the economic sphere of social development.

\section{Final Remarks}

Our study represents the first attempt to jointly investigate the relationship between ICT clusters, innovation and socially sustainable development. By analyzing the experience and evolution of Dongguan towns, we provide some evidence on the specific features that enable ICT clusters to become places that promote technological innovation as well as increased social development. In particular, our findings, suggest that specializing in ICT can pay in terms of innovative performances, provided that such specialization is supported by an institutional setting aimed at collectively promoting innovation, a sufficient degree of extra-cluster relations and a high enough level of education in the population. Results emphasize that, to achieve better innovative performances, Dongguan ICT clusters need to take further steps in both dimensions. These results also support the view that the competitive advantage of Chinese ICT clusters is still more related to the capacity of applying Western technology quickly than to endogenous knowledge and technology production (Wang et al., 2010). Despite attempts to favor the upgrading of clusters, most of them are still placed in the lower value added part of the GVC and dependent on mature economies for more sophisticated technologies (Lai et al., 2005; Sun \& Grimes, 2016; Zeng, 2010). 
More in general, these results call for attention on strengthening the future technological catch-up capacities of manufacturing locations within China which will be crucial in avoiding being trapped in a middle-income - and low-development - situation (Lavopa \& Szirmai, 2018). In this framework, our results can bring useful policy implications for the future planning of innovation policies. In particular, in order to encourage innovation, the government should aim at promoting higher degrees of education for the whole population. Part of the experience from developing countries suggests that this target, and in general broad growth and development goals, can be reached in particular by investing in training and education at the local level to grow local talents, rather than engaging in a global or national "talent war" (Leigh \& Blakely, 2016; Ng, 2011; Thite, 2011).

With respect to social sustainability, then, our results deepen the possible effects of ICT clustering. For its intrinsic features, ICT is potentially a trigger for higher innovative performances and can foster larger international exchange and more consistent linkages. However, this per se does not ensure that cumulative processes of social sustainability come into play. Indeed, while these features may help social development aspects that are more related to the economic status of the population and social services provision, they may fail in ensuring reductions of social inequality, social inclusion and social networks. Therefore, governments of developing countries targeting local ICT specialization should also design cluster policies including a punctual reflection on the local social sustainability, focusing in particular on the measures that specifically tackle social inclusion and bottom-up processes. A good starting point would be focusing on policies aimed at generating collective actions and ST program's innovation platform seems to be a good practice. Of course, these measures may need some time to deploy their effects in terms of building social networks. However, together with top-down measures aimed at generating joint actions in the economic sphere, territories can profitably gain from policies stimulating bottom-up dynamics aimed at building local inclusive communities. 
These results add evidence to the literature on the relationship between cluster economic performance and their social impact (Nadvi \& Barrientos, 2004; de Oliveira, 2008), and, more in general, to the linkage between innovation and human development (Capriati, 2017). In line with other contributions (Biggeri \& Ferrannini, 2014; Cai \& Sun, 2018; Garretsen et al., 2013; Ratigan, 2017; Zhang \& Hu, 2014) our evidence confirms the pivotal role of local governments' commitment in local development dynamics. They also reinforce, even at the local level, the view that globalization increasingly requires governments to be capable of "getting the policies right" in order to achieve various development goals (McMillan, Rodrik \& Verduzco-Gallo, 2014; UNIDO, 2015).

Finally, our study also presents some limitations. Firstly, the index we use to represent midterm objectives of social sustainability (SES) is observed only for a limited amount of time. Therefore, we cannot exclude that relevant cumulative processes of social development that also reinforce sustainability in the long run will take place in the future in Dongguan ICT clusters. Additionally, our conclusions are related to the specific, although relevant, case study of Dongguan city. More contributions on other territories specialized in ICT, or on large scale phenomena of ICT specialization, are needed in the future to add to our current findings.

\section{Data statement}

The research in this article did not generate any data or code and was based solely on documents in the public domain.

\section{References}

Acs, Z. J., Anselin, L., \& Varga, A. (2002). Patents and innovation counts as measures of regional production of new knowledge. Research policy, 31(7), 1069-1085. Doi: https://doi.org/10.1016/S0048-7333(01)00184-6

Acs, Z. J., \& Audretsch, D. B. (1987). Innovation, Market Structure, and Firm Size. The Review of Economics and Statistics, 69(4), 567. https://doi.org/10.2307/1935950

Amighini, A. (2005). China in the international fragmentation of production: Evidence from the ICT industry. The European Journal of Comparative Economics, 2(2), 203-220. 
Anand, S., \& Sen, A. (2000). Human development and economic sustainability. World development, 28(12), 20292049.

Arvanitis, R., \& Qiu, H. (2004). R\&D in universities and different institutional settings in South China: research for policy. Final research report for IDRC.

Asadullah, M. N., \& Savoia, A. (2018). Poverty reduction during 1990-2013: Did millennium development goals adoption and state capacity matter? World Development, 105, 70-82. https://doi.org/10.1016/j.worlddev.2017.12.010

Asongu, S. A., \& Le Roux, S. (2017). Enhancing ICT for inclusive human development in Sub-Saharan Africa. Technological Forecasting and Social Change, 118, 44-54. https://doi.org/10.1016/j.techfore.2017.01.026

Balauskat, A. Blamire, R. Kefala, S. (2012). The ICT impact report, European Commission.

Baptista, R., \& Swann, P. (1998). Do firms in clusters innovate more?. Research Policy, 27(5), 525-540. Doi: https://doi.org/10.1016/S0048-7333(98)00065-1

Baptista, R. (2000). Do innovations diffuse faster within geographical clusters? International Journal of Industrial Organization, 18, 515-535. https://doi.org/10.1016/S0167-7187(99)00045-4

Barbieri, E. Di Tommaso, M. R., \& Bonnini, S. (2012). Industrial development policies and performances in Southern China: Beyond the Specialized industrial cluster program. China Economic Review, 23(3) 613-625. Doi: https://doi.org/10.1016/j.chieco.2010.12.005

Barbieri, E., Di Tommaso, M. R., \& Huang, M. (2010). Industrial Development Policy and Innovation in Southern China: Government Targets and Firms’ Behaviour. European Planning Studies, 18(April 2015), 83-105. https://doi.org/10.1080/09654310903343542

Barbieri, E., Di Tommaso, M. R., Pollio, C., \& Rubini, L. (2019) Industrial Policy in China: The Planned Growth of Specialised Towns in Guangdong Province, mimeo, forthcoming.

Barbieri, E., Di Tommaso, M. R., \& Rubini, L. (2009a). Industria contemporanea nella Cina Meridionale: governi, imprese e territori. Carocci.

Barbieri, E., Di Tommaso, M. R, \& Rubini, L. (2009b). Industrial Development Policies in Southern China: The Specialized Towns Programme. Economia e Politica Industriale, 3.

Barca, F., McCann, P., \& Rodríguez-Pose, A. (2012). The case for regional development intervention: Place-based versus place-neutral approaches. Journal of Regional Science, 52(1), 134-152. https://doi.org/10.1111/j.14679787.2011.00756.x 
Becattini, G. (1990). The Marshallian industrial distirct as a socioeconomic notion. In F. Pyke \& W. Sengenberger (Eds.), Industrial districts and inter-firm co-operation in Italy (pp. 37-51). Geneva: International Labour Organization.

Becattini, G., \& Dei Ottati, G. (2006). The performance of Italian industrial districts and large enterprise areas in the 1990s. European Planning Studies, 14(8), 1139-1162. Doi: https://doi.org/10.1080/09654310600852423

Becattini, G. Bellandi, M., \& De Propris, L. (eds.) (2009), A Handbook of Industrial Districts, Cheltenham, UK, Northampton, USA: Edward Elgar.

Bell, M., \& Albu, M. (1999). Knowledge systems and technological dynamism in industrial clusters in developing countries. World Development, 27(9), 1715-1734. https://doi.org/10.1016/S0305-750X(99)00073-X

Bell, G. G. (2005). Clusters, networks, and firm innovativeness. Strategic management journal, 26(3), 287-295.

Bellandi, M., \& Di Tommaso, M. R. (2005). The case of specialized towns in Guangdong, China. European Planning Studies, 13(March 2015), 707-729. https://doi.org/10.1080/09654310500139244

Bellandi, M., \& Lombardi, S. (2012). Specialized markets and Chinese industrial clusters: The experience of Zhejiang Province. China Economc Review, 23(3), 626-638. Doi:https://doi.org/10.1016/j.chieco.2012.03.001

Bellandi, M. (2002). Modelli di analisi distrettuale e azione collettiva per lo sviluppo locale: alcuni spunti di riflessione. Economia Marche, 1, 89-98.

Biggeri, M., \& Ferrannini, A. (2014). Sustainable human development: A new territorial and people-centred perspective. Baskingstoke and New York: Palgrave McMillan.

Bolognini, A. (2000). Piccole imprese nella grande Cina. In Bianchi, P., Di Tommaso, M. R., \& Rubini L. (eds.) Le api audaci: piccole imprese e dinamiche industriali in estremo oriente, Milano: Franco Angeli.

Boström, M. (2012). A missing pillar? Challenges in theorizing and practicing social sustainability: Introduction to the special issue. Sustainability: Science, Practice, and Policy, 8(1), 3-14. https://doi.org/10.1080/15487733.2012.11908080

Breschi, S \& Malerba, F. (2005). Clusters, networks and innovation. Oxford: Oxford University Press.

Bresnahan, T., \& Gambardella, A. (2004). Building High-Tech Clusters: Silicon Valley and Beyond, Cambridge, Cambridge University Press.

Cai, M., \& Sun, X. (2018). Institutional bindingness, power structure, and land expropriation in China. World Development, 109, 172-186. https://doi.org/10.1016/J.WORLDDEV.2018.04.019

Cairns, M. R. (2018). Metering water : Analyzing the concurrent pressures of conservation, sustainability, health impact , and equity in use. World Development, 110, 411-421. https://doi.org/10.1016/j.worlddev.2018.06.001 
Cameron, A. C., \& Trivedi, P. K. (1998). Regression analysis using count data, Cambridge, UK: Cambridge University Press.

Cappellin, R. (2009). The analysis of regional innovation networks, in R. Cappellin \& W. Rudiger (eds.), International Knowledge and Innovation Networks. Knowledge Creation and Innovation in Medium-technology Clusters, Cheltenham, UK: Edward Elgar, 78-185.

Capriati, M. (2017). Capabilities, Innovation and Economic Growth: Policymaking for Freedom and Efficiency. Routledge.

Castellacci, F. (2008). Technological paradigms, regimes and trajectories: Manufacturing and service industries in a new taxonomy of sectoral patterns of innovation. Research Policy, 37(6-7), 978-994. https://doi.org/10.1016/j.respol.2008.03.011

Chandrashekar, D., \& Subrahmanya, M. H. B. (2019). Exploring the factors of cluster linkages that influence innovation performance of firms in a cluster. Economics of Innovation and New Technology, 28(1), 1-22. https://doi.org/10.1080/10438599.2017.1384102

Chen, B., Lu, M., \& Zhong, N. (2015). How Urban Segregation Distorts Chinese Migrants' Consumption? World Development, 70, 133-146. https://doi.org/10.1016/j.worlddev.2014.11.019

Chen, S. H. (2004). Taiwanese IT firms' offshore R\&D in China and the connection with the global innovation network. Research Policy, 33, 337-349. Doi: https://doi.org/10.1016/j.respol.2003.09.003

Cheng, J. Y. S., \& Peiyu, Z. (2001). Hi-Tech Industries in Hong Kong and the Pearl River Delta Development Trends in Industrial Cooperation. Asian Survey, 41(4), 584-610.

Chesbrough, H. (2003). Open Innovation: The New Imperative for Creating and Profiting from Technology. Boston, MA: Harward Business School Publishing.

Chiarvesio, M., Di Maria, E., \& Micelli, S. (2010). Global value chains and open networks: the case of Italian industrial districts. European Planning Studies, 18(3), 333-350.

Christerson, B., \& Lever-Tracy, C. (1997). The Third China? Emerging industrial districts in rural China. International Journal of Urban and Regional Research, 21(4), 569-588. https://doi.org/10.1111/1468-2427.00102

Coad, A., \& Rao, R. (2008). Innovation and firm growth in high-tech sectors: A quantile regression approach. Research Policy, 37(4), 633-648. Doi: https://doi.org/10.1016/j.respol.2008.01.003

Combes, P., Démurger, S., Li, S., \& Wang, J. (2019). Unequal migration and urbanisation gains in China. Journal of Development Economics, (January), 1-17. https://doi.org/10.1016/j.jdeveco.2019.01.009 
Cuthill, M. (2010). Strengthening the "social" in sustainable development: Developing a conceptual framework for social sustainability in a rapid urban growth region in Australia. Sustainable Development, 18(6), 362-373. https://doi.org/10.1002/sd.397

De Marchi, V., \& Grandinetti, R. (2014). Industrial districts and the collapse of the Marshallian model: looking at the Italian experience. Competition \& Change, 18(1), 70-87. https://doi.org/10.1179/1024529413Z.00000000049 de Oliveira, J. A. P. (Ed.). (2008). Upgrading clusters and small enterprises in developing countries: Environmental, labor, innovation and social issues. Ashgate Publishing, Ltd..

Dempsey, N., Bramley, G., Power, S., \& Brown, C. (2011). The social dimension of sustainable development: Defining urban social sustainability. Sustainable development, 19(5), 289-300.

Dakhli, M., \& De Clercq, D. (2004). Human capital, social capital, and innovation: A multi-country study. Entrepreneurship and Regional Development. https://doi.org/10.1080/08985620410001677835

Dei Ottati, G. (2002). Social concertation and local development: the case of industrial districts. European Planning Studies, 10(4), 449-466. Doi: https://doi.org/10.1080/09654310220130176

Dhahri, S., \& Omri, A. (2018). Entrepreneurship contribution to the three pillars of sustainable development: What does the evidence really say? World Development, 106, 64-77. https://doi.org/10.1016/j.worlddev.2018.01.008

Di Tommaso, M. R., Rubini, L., \& Barbieri, E. (2013). Southern China. Industry, Development and Industrial Policy. London and New York: Routledge.

Di Tommaso, M. R., \& Rubini, L. (2006). Cluster industriali e Specialized Towns nel Guangdong: la centralità del Delta del Fiume delle Perle. Il Fiume delle Perle: La Dimensione Locale dello Sviluppo Industriale Cinese e il Confronto con l'Italia. Rosenberg\&Sellier: Torino.

Disney, S. M., Naim, M. M., \& Potter, A. (2004). Assessing the impact of e-business on supply chain dynamics. International Journal of Production Economics, 89(2), 109-118. https://doi.org/10.1016/S0925-5273(02)004644

Dongguan Statistical Office (various years). Dongguan Statistical Yearbook.

DSTGG (Department of Science and Technology of Dongguan Government) (2017). A data analysis of the development of Specialized towns. Internal Report, July (in Chinese).

DSTGG (2006). Report on the Summary of the five-year Implementation of the Plan of ST Technology Innovation Pilot Test and an Overview of the Development of the STs, DSTGG Magazine on Specialized Towns Technology Innovation Dynamics, 15(6), 1-6 (in Chinese).

DSTGG (2003). The Innovation of Industrial Clusters in Guangdong, Internal Report, September (in Chinese). 
Eizenberg, E., \& Jabareen, Y. (2017). Social sustainability: A new conceptual framework. Sustainability (Switzerland), 9(1). https://doi.org/10.3390/su9010068

Elliott, R. J. R., \& Zhou, Y. (2015). Co-location and Spatial Wage Spillovers in China: The Role of Foreign Ownership and Trade. World Development, 66, 629-644. https://doi.org/10.1016/J.WORLDDEV.2014.09.001

Eraydin, A., \& Armatli-Köroğlu, B. (2005). Innovation, networking and the new industrial clusters: The characteristics of networks and local innovation capabilities in the Turkish industrial clusters. Entrepreneurship and Regional Development, 17(4), 237-266. https://doi.org/10.1080/08985620500202632

Etzkowitz, H. (2013). Silicon Valley at risk? Sustainability of a global innovation icon: An introduction to the Special Issue. Social Science Information, 52(4), 515-538.

European Commission (2010). An Integrated Industrial Policy for the Globalisation Era Putting Competitiveness and Sustainability at Centre Stage, Communication from the Commission to the European Parliament, the Council, the European Economic and Social Committee and the Committee of the Regions, Brussels, COM (2010) 614.

Fu, X., \& Gong, Y. (2011). Indigenous and Foreign Innovation Efforts and Drivers of Technological Upgrading:

Evidence from China. World Development. https://doi.org/10.1016/j.worlddev.2010.05.010

Gangnes B., \& Van Assche A. (2012). Global production networks in electronics and intra-Asian Trade, in Henckel, T. (ed.) Sustaining development and growth in East Asia, Routledge, Abigdon.

Garretsen, H., McCann, P., Martin, R., \& Tyler, P. (2013). The future of regional policy. Cambridge Journal of Regions, Economy and Society, 6(2), 179-186. https://doi.org/10.1093/cjres/rst013

GDASS (Guangdong Academy of Social Sciences) (2017). The Pattern and Path of Collaborative Innovation of Guangdong Industrial Clusters. Internal Report, July (in Chinese).

Gill, P., Stewart, K., Treasure, E., \& Chadwick, B. (2008). Methods of data collection in qualitative research: Interviews and focus groups. British Dental Journal, 204(6), 291-295. https://doi.org/10.1038/bdj.2008.192

Giuliani, E., Pietrobelli, C., \& Rabellotti, R. (2005). Upgrading in Global Value Chains: Lessons from Latin American Clusters. World Development, 33(4), 549-573. https://doi.org/10.1016/j.worlddev.2005.01.002

Godschalk, D. R. (2004). Land use planning challenges: coping with conflicts in visions of sustainable development and liveable communities. Journal of the American Planning Association, 70(1), 5-13. https://doi.org/10.1080/01944360408976334

Goertz, G. (2017). Multimethod Research, Causal Mechanisms, and Case Studies. An integrated approach, Princeton and Oxford: Princeton University Press. 
Gouvea, R., Kapelianis, D., \& Kassicieh, S. (2017). Assessing the nexus of sustainability and information \& communications technology. Technological Forecasting and Social Change, (June), 0-1. https://doi.org/10.1016/j.techfore.2017.07.023

Griliches, Z. (1990). Patent statistics as economic indicators: a survey, National Bureau of Economic Research Working Paper, No. w3301.

Guangdong Statistical Office (2016). Guangdong Statistical Yearbook.

Haraguchi, N., Cheng, C. F. C., \& Smeets, E. (2017). The Importance of Manufacturing in Economic Development: Has This Changed? World Development, 93, pp.293-315. http://dx.doi.org/10.1016/j.worlddev.2016.12.013. Hausman, J., Hall, B. H., \& Griliches, Z. (1984). Econometric Models for Count Data with an Application to the Patents-R \& D Relationship. NBER Technical Working Paper No. 17. Doi: 10.3386/t0017

He, J., \& Fallah, M. H. (2011). The typology of technology clusters and its evolution. Evidence from the hi-tech industries. Technological Forecasting \& Social Change, 78(6), 945-962. https://doi.org/10.1016/j.techfore.2011.01.005

Hesse-Biber, S., \& Johnson, R. B. (eds.) (2015), The Oxford Handbook of Multimethod and Mixed Methods Research Inquiry, Oxford, New York: Oxford University Press.

Hilbe, J. M. (2011). Negative Binomial Regression Second Edition, Cambridge, UK: Cambridge University Press.

Hu, M. C., \& Mathews, J. A. (2008). China's national innovative capacity. Research Policy, 37(9), 1465-1479. Doi: https://doi.org/10.1016/j.respol.2008.07.003

Hughes, B. B., Bohl, D., Irfan, M., Margolese-Malin, E., \& Solórzano, J. R. (2017). ICT/Cyber benefits and costs: Reconciling competing perspectives on the current and future balance. Technological Forecasting and Social Change, 115, 117-130. https://doi.org/10.1016/J.TECHFORE.2016.09.027

Iammarino, S. (2018). FDI and regional development policy. Journal of International Business Policy, 1 (3-4). pp. 157183. https://doi.org/10.1057/s42214-018-0012-1

Ip, I. C. (2014). Urbanisation, the State, and Community Activism in the Pearl River Delta: The case of a land dispute in Dongguan. China Perspectives, 2.

Jian, W., Chan, K. Y., Reidpath, D. D., \& Xu, L. (2010). China’s Rural-Urban Care Gap Shrank For Chronic Disease Patients, But Inequities Persist. Health Affairs, 29(12), 2189-2196. https://doi.org/10.1377/hlthaff.2009.0989 Keeble, D., \& Wilkinson, F. (1999). Collective Learning and Knowledge Development in the Evolution of Regional Clusters of High Technology SMEs in Europe. Regional Studies, 33(4), 295-303. https://doi.org/10.1080/00343409950081167 
Lai, H.-C., Chiu, Y.-C., \& Leu, H.-D. (2005). Innovation Capacity Comparison of China's Information Technology Industrial Cluster: The Case of Shanghai, Kushan, Shenzhen and Dongguan. Technology Analysis \& Strategic Management, 17(3), 239-315. Doi: https://doi.org/10.1080/09537320500211284

Lavopa, A., \& Szirmai, A. (2018). Structural modernisation and development traps. An empirical approach. World Development, 112, 59-73. https://doi.org/10.1016/J.WORLDDEV.2018.07.005

Lechman, E., \& Marszk, A. (2015). ICT technologies and financial innovations: The case of exchange traded funds in Brazil, Japan, Mexico, South Korea and the United States. Technological Forecasting and Social Change, 99 , 355-376. https://doi.org/10.1016/j.techfore.2015.01.006

Lee, H. J. Lee, S., \& Yoon, B. (2011). Technology clustering based on evolutionary patterns: The case of information and communication technologies. Technological Forecasting \& Social Change, 78(6), 953-967. Doi: https://doi.org/10.1016/j.techfore.2011.02.002

Lee, S., Nam, Y., Lee, S., \& Son, H. (2016). Determinants of ICT innovations: A cross-country empirical study. Technological Forecasting \& Social Change, 110, 71-77. https://doi.org/10.1016/j.techfore.2015.11.010

Leigh, N. G., \& Blakely, E. J. (2016). Planning local economic development: Theory and practice. Sage Publications.

Lele, S. M. (1991). Sustainable development: a critical review. World development, 19(6), 607-621.

Lin, G. C. S., Wang, C. C., Zhou, Y., Sun, Y., \& Wei, Y. D. (2011). Placing Technological Innovation in Globalising China. Urban Studies, 48(14), 2999-3018. https://doi.org/10.1177/0042098010396232

Lin, G. C. (2006). Peri-urbanism in globalizing China: A study of new urbanism in Dongguan. Eurasian Geography and Economics, 47(1), 28-53.

Linders, D. (2012). From e-government to we-government: Defining a typology for citizen coproduction in the age of social media. Government Information Quarterly, 29(4), 446-454. https://doi.org/10.1016/j.giq.2012.06.003

Littig, B., \& Grießler, E. (2005). Social sustainability: a catchword between political pragmatism and social theory. International Journal of Sustainable Development, 8(1/2), 65-79.

Liu, Y., \& Ye, Q. (2015). Territorialization and territorial politics in the urban grassroots of China: A case study of the Dongtai community in Dongguan city. Dili Xuebao/Acta Geographica Sinica, 70(2), 283-296.

Long, J. S., \& Freese, J. (2014). Regression Models For Categorical Dependent Variables Using Stata, Third Ed., College Station, TX: Stata Press.

Lu, P. (2006). Specialized town is the Strong Engine to Drive the Economy of Guangdong: the Five-year Development of Specialized Town Technology Innovation Pilot Test, Journal of Guangdong Science and Technology, 8, 1-4 (in Chinese) 
Lundvall, B. A. (2007). Innovation System Resarch: Where It Came From and Where It Might Go, Globelix Working Paper, No. 2007-01.

Lundvall, B. A., Joseph, K. J., Chaminade, C., \& Vang, J. (2009). Handbook of Innovation System and Developing Countries: Building Domestic Capabilities in a Global Setting. Cheltenham, UK; Northampton, Edward Elgar Publishing Ltd.

Luo, X., \& Zhu, N. (2015). Hub-Periphery Development Pattern and Inclusive Growth Case Study of Guangdong Province. Policy Research Working Paper, n. 7509.

Lyons, G. (2009). The reshaping of activities and mobility through new technologies. Journal of Transport Geography, 17(2), 81-82. https://doi.org/10.1016/j.jtrangeo.2008.12.001

Ma, Z., Lee, Y., \& Chen, C.-F. P. (2009). Booming or emerging? China's technological capability and international collaboration in patent activities. Technological Forecasting and Social Change, 76(6), 787-796. https://doi.org/10.1016/J.TECHFORE.2008.11.003

Magis, K., \& Shinn, C. (2009). Emergent principles of social sustainability. Understanding the social dimension of sustainability, in Dillard, J., Dujon, V., \& King M. C. (eds.) Understanding the social dimension of sustainability, Routledge: 15-44.

Manning, S., Ricart, J. E., Rosatti Rique, M. S., \& Lewin, A. Y. (2010). From blind spots to hotspots: How knowledge services clusters develop and attract foreign investment. Journal of International Management, 16(4), 369-382. https://doi.org/10.1016/J.INTMAN.2010.09.007

Marinov, M., \& Marinova, S. (eds.) (2012). Emerging Economies and Firms in the Global Crisis. Palgrave Macmillan. Mariotti, S., Mutinelli, M., \& Piscitello, L. (2008). The internationalization of production by Italian industrial districts' firms: structural and behavioural determinants. Regional Studies, 42(5), 719-735.

Marshall, A. (1890). Principles of Economics. London: Macmillan.

Martin, R. (2010). Roepke lecture in economic geography. Rethinking regional path dependence: beyond lock-in to evolution. Economic Geography, 86(1), 1-27.

McMillan, M., Rodrik, D., \& Verduzco-Gallo, Í. (2014). Globalization, Structural Change, and Productivity Growth, with an Update on Africa. World Development, 63, 11-32. https://doi.org/10.1016/J.WORLDDEV.2013.10.012

Menghinello, S., De Propris, L., \& Driffield, N. (2010). Industrial districts, inward foreign investment and regional development. Journal of Economic Geography, 10(4), 539-558.

Min, W., \& Lu, Y. (2007). Endogenous Innovation in Chinese IC Firms: A Case Study Based on the Technology Strategy Evolution of NSBIC. Journal of Electronic Science and Technology, 4(4), 407-411. 
Morrison, A., Pietrobelli, C., \& Rabellotti, R. (2008). Global Value Chains and Technological Capabilities: A Framework to Study Learning and Innovation in Developing Countries. Oxford Development Studies, 36(1), 39_ 58. https://doi.org/10.1080/13600810701848144

Nadvi, K., \& Barrientos, S. (2004). Industrial Clusters and Poverty Reduction Towards a methodology for poverty and social impact assessment of cluster development initiatives. Vienna: UNIDO.

Ng, P. T. (2011). Singapore's response to the global war for talent: Politics and education. International Journal of Educational Development, 31(3), 262-268. Doi: https://doi.org/10.1016/j.ijedudev.2010.05.009

Niebel, T. (2018). ICT and economic growth - Comparing developing, emerging and developed countries. World Development, 104, 197-211. https://doi.org/10.1016/j.worlddev.2017.11.024

NLC (National Labour Committee) (2009). High Tech Misery in China: The Dehumanization of Young Workers Producing our Computer Keyboards, Pittsburg.

Okamuro, H., \& Nishimura, J. (2013). Impact of university intellectual property policy on the performance of university-industry research collaboration. The Journal of Technology Transfer, 38(3), 273-301. https://doi.org/10.1007/s10961-012-9253-Z

Ollo-López, A., \& Aramendía-Muneta, M. E. (2012). ICT impact on competitiveness, innovation and environment. Telematics and Informatics, 29(2), 204-210. https://doi.org/10.1016/j.tele.2011.08.002

Pellow, D. N., \& Park, L. S.-H. (2002). The Silicon Valley of dreams, New York, New York University Press. Pietrobelli, C., \& Rabellotti, R. (2011). Global Value Chains Meet Innovation Systems: Are There Learning Opportunities for Developing Countries? World Development, 39(7), 1261-1269. https://doi.org/10.1016/j.worlddev.2010.05.013

Piore, M. J., \& Sabel, C. F. (1986). The second industrial divide: possibilities for prosperity, Basic Books.

Pique, M. J., Berbegal-Mirabent, J., \& Etzkowitz, H. (2018). Triple elix and the evolution of eco-systems of innovation: The case of Silicon Valley. Triple Helix, 5:11

Pollio, C., Barbieri, E., Rubini, L., \& Di Tommaso, M. R. (2016). Attrarre basta per innovare? La via cinese nell'industria dell'auto. L'industria, XXXVII(4), 5-32. https://doi.org/10.1430/86050

Pope, C., \& Mays, N. (1995). Reaching the parts other methods cannot reach: an introduction to qualitative methods in health and health service research. British Medical Journal, 311, 42-45.

Porter, M. (1999). Clusters and the new economics of competition. Harvard Business Review, 76(6), 77-90.

Porter, M., \& Ketels, C. (2009). Clusters and industrial districts: Common roots, different perspectives, in G. Becattini, M. Bellandi \& L. De Propris (eds.) Handbook of industrial districts, Edward Elgar Publisher, 172-183. 
Pyke, F., \& Sengenberger, W. (eds.) (1990). Industrial districts and local economic regeneration. Geneva, International Labour Organisation.

Rasiah, R., Shahrivar, R. B., \& Yap, X. S. (2016). Institutional support, innovation capabilities and exports: Evidence from the semiconductor industry in Taiwan. Technological Forecasting and Social Change, 109, 69-75. Doi: https://doi.org/10.1016/j.techfore.2016.05.015

Ratigan, K. (2017). Disaggregating the Developing Welfare State: Provincial Social Policy Regimes in China. World Development, 98, 467-484. https://doi.org/10.1016/J.WORLDDEV.2017.05.010

Rocha, H. (2004). Entrepreneurship and development: The role of clusters. Small Business Economics, 23(5), 363-400. https://doi.org/10.1007/s11187-004-3991-8

Rubini, L., Pollio, C., \& Di Tommaso, M. R. (2017). Transnational Research Networks in Chinese Scientific Production. An Investigation on Health-Industry Related Sectors. International Journal of Environmental Research and Public Health, 14(9). https://doi.org/10.3390/ijerph14090975

Sachs, J. D. (2012). From Millennium Development Goals to Sustainable Development Goals. Lancet, 379, $2206-2211$. https://doi.org/10.1016/S0140-6736(12)60685-0

Salomon, R. M., \& Shaver, J. M. (2005). Learning by exporting: New insights from examining firm innovation. Journal of Economics and Management Strategy. https://doi.org/10.1111/j.1530-9134.2005.00047.x

Sen, A. (1997). Human Capital and Human Capabilities, World Development, 25(12), 1959-61.

Shen, X., \& Tsai, K. S. (2016). Institutional Adaptability in China: Local Developmental Models Under Changing Economic Conditions. World Development, 87, 107-127. https://doi.org/10.1016/j.worlddev.2016.06.010

Shirazi, M. R., \& Keivani, R. (2017). Critical reflections on the theory and practice of social sustainability in the built environment-a meta-analysis. Local Environment, 22(12), 1526-1545. https://doi.org/10.1080/13549839.2017.1379476

Song, Y. (2014). What should economists know about the current Chinese hukou system? China Economic Review, 29, 200-212. Doi: http://doi.org/10.1016/j.chieco.2014.04.012.

Steinmueller, W. E. (2001). ICTs and the possibilities for leapfrogging by developing countries. International Labour Review, 140(2), 193-210.

Strezov, V., Evans, A., \& Evans, T. J. (2017). Assessment of the Economic, Social and Environmental Dimensions of the Indicators for Sustainable Development. Sustainable Development, 25(3), 242-253. https://doi.org/10.1002/sd.1649

Sun, Y., \& Grimes, S. (2016). China's increasing participation in ICT’s global value chain: A firm level analysis. Telecommunications Policy, 40(2-3), 210-224. Doi: https://doi.org/10.1016/j.telpol.2015.06.003 
Sun, Y., \& Zhou, Y. (2011). Innovation and Inter-Firm Technological Networking: Evidence From China's Information Communication Technology Industry. Erdkunde, 65(1 (January-March)), 55-70. https://doi.org/10.2307/25822131

Thite, M. (2011). Smart cities: implications of urban planning for human resource development. Human Resource Development International, 14(5) 623-631. Doi: https://doi.org/10.1080/13678868.2011.618349

Thompson, E. R. (2002). Clustering of foreign direct investment and enhanced technology transfer: Evidence from Hong Kong garment firms in China. World Development, 30(5), 873-889. https://doi.org/10.1016/S0305$750 \mathrm{X}(02) 00009-8$

Tisdell, C. (1988). Sustainable development: differing perspectives of ecologists and economists, and relevance to LDCs. World development, 16(3), 373-384.

Treiman, D. J. (2012). The "difference between heaven and earth": Urban-rural disparities in well-being in China. Research in Social Stratification and Mobility, 30(1), 33-47. https://doi.org/10.1016/J.RSSM.2011.10.001 UNDP (United Nations Development Program) (2016). Human Development Report: Technical Notes.

UNDP (2018). Human Development Indices and Indicators 2018. Statistical Update.

https://doi.org/10.18356/656a3808-en

UNIDO (United Nations Industrial Development Organization) (2015a). Inclusive and Sustainable Industrial Development. Creating shared prosperity, Safeguarding the environment, Presentation Brochure, Vienna.

UNIDO (2015b). Inclusive and Industrial Sustainable Development in Asia and Pacific Region, Vienna.

United Nations (2018). UN Secretary-General's Strategy on New Technologies.

United Nations (2015). Transforming our world: The 2030 agenda for sustainable development. Resolution adopted by the General Assembly.

Vallance, S., Perkins, H. C., \& Dixon, J. E. (2011). What is social sustainability? A clarification of concepts. Geoforum, 42(3), 342-348. https://doi.org/10.1016/j.geoforum.2011.01.002

Wang, C. C., Lin, G. C. S., \& Li, G. (2010). Industrial Clustering and Technological Innovation in China: New Evidence from the ICT Industry in Shenzhen. Environment and Planning A, 42(8), 1987-2010. https://doi.org/10.1068/a4356

Wang, C., \& Lin, G. C. S. (2008). The Growth and Spatial Distribution of China's ICT Industry: New Geography of Clustering and Innovation. Issues \& Studies, 44(2), 145-192. 
Wang, J., \& Mei, L. (2009). Trajectories and Prospects of industrial districts in China. In Becattini, G. Bellandi, M., \& De Propris, L. (eds.), A Handbook of Industrial Districts, Cheltenham, UK, Northampton, USA: Edward Elgar.

Wang, J., \& Yue, F. (2010). Cluster development and the role of government: the case of Xiqiao textile cluster in Guangdong. In D. Z. Zeng (Ed.), Building engines for growth and competitiveness in China: Experience with special economic zones and industrial clusters. World Bank Publications.

Wang, J. (2004). Developing innovation based industrial clusters: policy recommendation, Economic Geography, 7( 433) (in Chinese).

Wang, J. (2009). Interaction and innovation in cluster development: some experiences from Guangdong province,

China. In B. Ganne \& Y. Lecler (Eds.), Asian Industrial Clusters, Global Competitiveness and New Policy Initiatives (pp. 325-362). World Scientific.

WCED (World Commission on Environment and Development) (1987). Our common future. Oxford: Oxford University Press.

Wei, Y. D. H. D., Li, W. M., \& Wang, C. B. (2007). Restructuring industrial districts, scaling up regional development: A study of the Wenzhou model, China. Economic Geography, 83(4), 421-444. https://doi.org/10.1111/j.19448287.2007.tb00381.x

Wilcoxon, F. (1945). Individual Comparisons by Ranking Methods. Biometrics Bulletin, 1(6), 80. https://doi.org/10.2307/3001968

Williams, R. (2012). Using the margins command to estimate and interpret adjusted predictions and marginal effects. Stata Journal, 12(2), 308-331.

Xing, W., Ye, X., \& Kui, L. (2011). Measuring convergence of China's ICT industry: An input-output analysis. Telecommunications Policy, 35 (4), 301-313.

Yang, C., \& Liao, H. (2010). Industrial agglomeration of Hong Kong and Taiwanese manufacturing investment in China: A town-level analysis in Dongguan. Annals of Regional Science, 45(3), 487-517. https://doi.org/10.1007/s00168-009-0305-8

Yang, C. (2007). Divergent hybrid capitalisms in China: Hong Kong and Taiwanese electronics clusters in Dongguan. Economic Geography, 83(4), 395-420. https://doi.org/10.1111/j.1944-8287.2007.tb00380.x

Yang, C. H., Motohashi, K., \& Chen, J. R. (2009). Are new technology-based firms located on science parks really more innovative?: Evidence from Taiwan. Research policy, 38(1), 77-85. https://doi.org/10.1016/j.respol.2008.09.001 
Zeng, D. Z. (2010). How do special economic zones and industrial clusters drive China's rapid development? In D.Z. Zeng (ed.), Building engines for growth and competitiveness in China. Experience with special economic zones and industrial clusters, Washington: The World Bank, 1-53-

Zhang, H. (2017). Opportunity or new poverty trap: Rural-urban education disparity and internal migration in China.

China Economic Review, 44, 112-124. https://doi.org/10.1016/J.CHIECO.2017.03.011

Zhang, X., \& Hu, D. (2014). Overcoming successive bottlenecks: The evolution of a potato cluster in China. World Development, 63(7082), 102-112. https://doi.org/10.1016/j.worlddev.2013.10.003

Zhan, S. (2011). What Determines Migrant Workers' Life Chances in Contemporary China? Hukou, Social Exclusion, and the Market. Modern China, 37(3), 243-285. https://doi.org/10.1177/0097700410379482

Zhou, Y. (2013). Time and spaces of China's ICT industry. In Cooke, P., Searle, G., \& O'Connor, K. (Eds.). The economic geography of the IT industry in the Asia Pacific Region. Abingdon, Routledge.

Zhou, Y., Sun, Y., Wei, Y. H. D., \& Lin, G. C. S. (2011). De-centering 'spatial fix'-patterns of territorialization and regional technological dynamism of ICT hubs in China. Journal of Economic Geography, 11(1), 119-150. https://doi.org/10.1093/jeg/lbp065

Appendix

List of institutions visited during July-August 2017 fieldwork:

- Department of Commerce of Guangzhou City

- Guangdong Provincial Department of Science and Technology

- Development and Reform Commission of Guangdong

- $\quad$ Guangdong Academy of Social Sciences

- Guangzhou Academy of Social Sciences

- South China University of Technology (School of Business Administration, School of Economics)

- Department of Economics of Shenzhen University (Guangdong)

- $\quad$ Changping Town (Dongguan) Local Government representatives

- $\quad$ Songshan Lake Hi-Tech Industrial Development Zone representatives 
- $\quad$ Ronggui Town (Foshan) Local Government Reprentatives

Table A1. Summary statistics for independent variables - innovation

\begin{tabular}{|c|c|c|c|c|c|c|}
\hline & Variable & Observations & Mean & Std. Dev. & Min & Max \\
\hline (1) & ICT & 479 & 0.204 & 0.403 & 0 & 1 \\
\hline (2) & No OCS & 479 & 0.515 & 0.500 & 0 & 1 \\
\hline (3) & ICT experience & 479 & -0.094 & 4.145 & -12 & 16 \\
\hline (4) & Capital intensity & 479 & 10.341 & 19.788 & 0.297 & 304.794 \\
\hline (5) & Foreign firms & 479 & 313.9624 & 246.514 & 26 & 1619 \\
\hline (6) & Export $_{t-1}$ & 479 & 183479.1 & 198921.4 & 4624 & 1847282 \\
\hline (7) & Secondary graduates $\mathrm{t}_{\mathrm{t}-1}$ & 479 & 0.029 & 0.011 & 0 & 0.090 \\
\hline
\end{tabular}

Table A2. Correlation table for independent variables - Innovation

\begin{tabular}{cccccccc}
\hline & $(1)$ & $(2)$ & $(3)$ & $(4)$ & $(5)$ & $(6)$ & $(7)$ \\
\hline$(1)$ & 1 & & & & & & \\
$(2)$ & $-0.5346^{* * *}$ & 1 & & & & & \\
$(3)$ & $0.6038^{* * *}$ & $-0.4065^{* * *}$ & 1 & & & & \\
$(4)$ & $-0.0923^{* *}$ & $0.1220^{* * *}$ & -0.0365 & 1 & & & \\
$(5)$ & $0.3151^{* * *}$ & $-0.2926^{* * *}$ & $0.0876^{* *}$ & $-0.1105^{* *}$ & 1 & & \\
(6) & $0.4612^{* * *}$ & $-0.3677^{* * *}$ & $0.2839^{* * *}$ & $-0.1139^{* * *}$ & $0.7181^{* * *}$ & 1 & \\
(7) & $0.2229^{* * *}$ & $-0.2263^{* * *}$ & $0.1249^{* * *}$ & $-0.1242^{* * *}$ & $0.4147^{* * *}$ & $0.3223^{* * *}$ & 1.0000
\end{tabular}

Significance: $* 10 \%, * * 5 \%, * * * 1 \%$.

Table A3. Summary statistics and correlation for social sustainability indices components

\begin{tabular}{|c|c|c|c|c|c|c|c|c|c|c|}
\hline & & Obs & Mean & St. dev & Min & Max & GDPpc & GrP & GrS & Beds \\
\hline \multirow{4}{*}{ TOSDI } & GDPpc & 479 & 19.4785 & 14.6543 & 1.7377 & 88.0731 & 1 & & & \\
\hline & $G r P$ & 479 & 0.0442 & 0.0222 & 0.0105 & 0.1537 & $0.7954^{* * *}$ & 1 & & \\
\hline & GrS & 479 & 0.0290 & 0.0112 & 0 & 0.0895 & $0.6106^{* * *}$ & $0.7794 * * *$ & 1 & \\
\hline & Beds & 479 & 98.3967 & 82.4435 & 4.3874 & 403.6012 & $0.6679 * * *$ & $0.6512 * * *$ & $0.4564 * * *$ & 1 \\
\hline \multirow{6}{*}{$B O N$} & & & & & & & GrP & GDPpc & $U R r$ & $S M$ \\
\hline & GrP & 480 & 0.044154 & 0.022219 & 0.010527 & 0.153726 & 1 & & & \\
\hline & $G D P p c$ & 480 & 19.45504 & 14.64801 & 1.737675 & 88.07306 & $0.7954 * * *$ & 1 & & \\
\hline & $U R r$ & 480 & 840.134 & 8730.615 & 0.0449 & 131469 & 0.0005 & $0.0893 *$ & 1 & \\
\hline & $S M$ & 480 & 22.47708 & 15.91206 & 3 & 95 & $0.1783^{* * *}$ & $0.2080 * * *$ & $0.3237 * * *$ & 1 \\
\hline & & & & & & & REr & $s W r$ & $R R r$ & \\
\hline \multirow{3}{*}{ SES } & $R E r$ & 224 & 1.0751 & 0.3866 & 0.0775 & 3.3281 & 1 & & & \\
\hline & $s W r$ & 224 & 0.0007 & 0.0006 & 0 & 0.0042 & $0.2463^{* * *}$ & 1 & & \\
\hline & $R R r$ & 224 & 2863.65 & 1969.22 & 657.89 & 10947.90 & -0.0279 & $0.2441 * * *$ & 1 & \\
\hline
\end{tabular}

Significance: $* 10 \%, * * 5 \%, * * * 1 \%$.

Table A4. Summary statistics for independent variables - Social sustainability 


\begin{tabular}{lllllll}
\hline & Variable & Obs & Mean & St. dev & Min & Max \\
\hline (1) & ICT & 480 & 0.204 & 0.404 & 0 & 1 \\
(2) No OCS & 480 & 0.515 & 0.500 & 0 & 1 \\
(3) & ICT experience & 480 & -0.094 & 4.140 & -12 & 16 \\
(4) Cumulative SIPO & 480 & 2828.863 & 4236.530 & 21 & 36604 \\
(5) & Total firms & 480 & 14665.560 & 14271.290 & 398 & 122204 \\
(6) & Exports/GDP ratio & 480 & 0.180 & 0.117 & 0.0140 & 0.6822 \\
(7) & Foreign/Local firms ratio & 480 & 0.032 & 0.031 & 0.002 & 0.239 \\
(8) Cumulative net migration & 480 & 5377.710 & 6733.405 & -233 & 46496 \\
\hline
\end{tabular}

Table A5. Correlation table for independent variables - Social sustainability

\begin{tabular}{ccccccccc}
\hline \multicolumn{2}{c}{$(1)$} & $(2)$ & $(3)$ & $(4)$ & $(5)$ & $(6)$ & $(7)$ & $(8)$ \\
\hline$(1)$ & 1 & & & & & & & \\
$(2)$ & $-0.5215^{* * *}$ & 1 & & & & & & \\
$(3)$ & $0.6276^{* * *}$ & $-0.3969 * * *$ & 1 & & & & & \\
$(4)$ & $0.3610^{* * *}$ & $-0.3379^{* * *}$ & $0.3153^{* * *}$ & 1 & & & & \\
$(5)$ & $0.3216^{* * *}$ & $-0.3351^{* * *}$ & $0.1614^{* * *}$ & $0.6648^{* * *}$ & 1 & & \\
$(6)$ & $0.3159^{* * *}$ & -0.0739 & -0.0007 & 0.0101 & $0.0943^{* *}$ & 1 & \\
$(7)$ & $-0.1241^{* * *}$ & $0.2004^{* * *}$ & $-0.1137^{* *}$ & $-0.1483^{* * *}$ & $-0.3204^{* * *}$ & 0.0634 & 1 & \\
$(8)$ & $0.1426^{* * *}$ & -0.0608 & $0.1177^{* * *}$ & $0.5970^{* * *}$ & $0.5247^{* * *}$ & $-0.1891^{* * *}$ & $-0.1505^{* * *}$ & 1 \\
\hline
\end{tabular}

Significance: $* 10 \%, * * 5 \%, * * * 1 \%$.

Table A6. The effect of certified ICT specialization on SIPO - raw coefficients

\begin{tabular}{|c|c|c|c|c|c|}
\hline & \multicolumn{2}{|c|}{ GLM } & \multicolumn{2}{|c|}{ Unconditional Fixed Effects } & \multirow{3}{*}{$\begin{array}{c}\text { Conditional } \\
\text { Fixed Effect } \\
\text { Poisson }\end{array}$} \\
\hline & & Negative & Poisson & Negative & \\
\hline & Poisson & Binomial & & & \\
\hline \multirow[t]{2}{*}{ ICT } & $-0.183^{* *}$ & $-0.145^{*}$ & -0.230 & -0.0711 & -0.230 \\
\hline & $(-2.39)$ & $(-1.68)$ & $(-1.48)$ & $(-0.66)$ & $(-1.48)$ \\
\hline \multirow[t]{2}{*}{ No OCS } & -0.060 & $-0.159 * *$ & $-0.210 * *$ & $-0.269 * * *$ & $-0.210 * *$ \\
\hline & $(-0.71)$ & $(-2.21)$ & $(-2.53)$ & $(-3.47)$ & $(-2.53)$ \\
\hline \multirow[t]{2}{*}{ Capital intensity } & -0.003 & $-0.004 * * *$ & 0.002 & 0.001 & 0.002 \\
\hline & $(-0.55)$ & $(-3.39)$ & $(0.38)$ & $(0.83)$ & $(0.38)$ \\
\hline \multirow[t]{2}{*}{ Total firms } & $0.00001 * * *$ & $0.00003^{* * *}$ & $0.000004 *$ & 0.000004 & $0.000004^{*}$ \\
\hline & (3.17) & $(7.80)$ & (1.87) & (1.60) & $(1.87)$ \\
\hline \multirow[t]{2}{*}{ Export $_{t-1}$} & $0.000001 * * *$ & $0.000001^{* * *}$ & 0.0000005 & 0.0000003 & 0.0000005 \\
\hline & $(6.03)$ & $(5.04)$ & $(0.90)$ & $(1.10)$ & $(0.90)$ \\
\hline \multirow{2}{*}{ Foreign firms } & $0.001 * * *$ & $0.001 * * *$ & $0.0004^{* * *}$ & $0.0003^{*}$ & $0.0004^{* * *}$ \\
\hline & $(6.73)$ & $(4.93)$ & (3.73) & $(1.80)$ & (3.73) \\
\hline \multirow{2}{*}{ Secondary graduates $s_{\mathrm{t}-1}$} & 0.770 & 0.0443 & $13.97 * * *$ & $5.003 *$ & $13.97 * * *$ \\
\hline & $(0.30)$ & $(0.01)$ & $(2.79)$ & $(1.83)$ & $(2.79)$ \\
\hline \multirow{2}{*}{ Constant } & $4.845^{* * *}$ & $4.702 * * *$ & No & $5.066 * * *$ & No \\
\hline & $(29.91)$ & $(42.36)$ & & $(35.01)$ & \\
\hline Effect of change in statistics & Yes & Yes & Yes & Yes & Yes \\
\hline Town fixed effects & No & No & Yes & Yes & Yes \\
\hline $\mathrm{N}$ & 448 & 448 & 448 & 448 & 448 \\
\hline LI & -31576.6 & -2857.7 & -13990.1 & -2679.2 & -13990.1 \\
\hline Bic & 63220.3 & 5782.5 & 28041.3 & 5614.7 & 28041.3 \\
\hline Aic & 63175.1 & 5737.3 & 28000.2 & 5442.3 & 28000.2 \\
\hline Dispersion & 137.1 & 1.088 & . & 1.162 & . \\
\hline chi2_c & 1606.2 & 1294 & 3741.6 & 3600.8 & 3741.6 \\
\hline
\end{tabular}


Significance: $* 10 \%, * * 5 \%, * * * 1 \%$. 